University of Rhode Island

DigitalCommons@URI

Open Access Master's Theses

2020

\title{
TROPHIC NICHE OVERLAP OF ATLANTIC COD AND BLACK SEA BASS IN RELATION TO WARMING SOUTHERN NEW ENGLAND WATERS
}

Nina Santos

University of Rhode Island, nrsantos@uri.edu

Follow this and additional works at: https://digitalcommons.uri.edu/theses

\section{Recommended Citation}

Santos, Nina, "TROPHIC NICHE OVERLAP OF ATLANTIC COD AND BLACK SEA BASS IN RELATION TO WARMING SOUTHERN NEW ENGLAND WATERS" (2020). Open Access Master's Theses. Paper 1915. https://digitalcommons.uri.edu/theses/1915

This Thesis is brought to you for free and open access by DigitalCommons@URI. It has been accepted for inclusion in Open Access Master's Theses by an authorized administrator of DigitalCommons@URI. For more information, please contact digitalcommons-group@uri.edu. 
TROPHIC NICHE OVERLAP OF ATLANTIC COD AND

BLACK SEA BASS IN RELATION TO WARMING

SOUTHERN NEW ENGLAND WATERS

BY

NINA SANTOS

A THESIS SUBMITTED IN PARTIAL FULFILLMENT OF THE

REQUIREMENTS FOR THE DEGREE OF

MASTER OF SCIENCE

IN

OCEANOGRAPHY

UNIVERSITY OF RHODE ISLAND

2020 
MASTER OF SCIENCE THESIS

$\mathrm{OF}$

NINA SANTOS

APPROVED:

Thesis Committee:

Major Professor: Kelton McMahon

Jeremy Collie

Scott McWilliams

Brenton Deboef

DEAN OF THE GRADUATE SCHOOL

UNIVERSITY OF RHODE ISLAND

2020 


\begin{abstract}
In southern New England (SNE), a new ecological interaction is occurring as temperate black sea bass abundance increases in the home range of the iconic Atlantic cod as a result of climate-induced ocean warming. In this study, we examined the diet and trophic dynamics of both SNE Atlantic cod and black sea bass using a multi-tracer approach of stomach content analysis as well as bulk and compound-specific amino acid isotope analyses. We reveal a highly selective diet (0.01-0.43 Levin's index) with decapod crustaceans occurring in $82-89 \%$ of stomachs and making up $72-79 \%$ of the total wet weight for both species, resulting in strong overlap in diet (0.34-0.99 Morisita-Horn index). The most prominent decapod crustacean seen in stomachs were juveniles of the Cancer genus, which has cascading implications for Jonah crab (Cancer borealis) population dynamics and the burgeoning SNE fishery they support. We also reveal high overlap (30$85 \%$ ) in isotopic niche between species. We show a seasonal shift in $\delta^{15} \mathrm{~N}$ Phe, which reflects changes in regional productivity but also indicates that both species are foraging locally in relatively small ranges relative to cross shelf isotope gradients and in the same locations seasonally. Our trophic position estimations corroborate our diet information and further reveal that cod (3.5-4.1) and black sea bass (3.4-3.5) generally occupy the same trophic position in the food web with high diet selectivity for crustaceans. This work reveals the potential for future shifts in SNE food web dynamics and the fisheries they support, while serving as a case study for future studies in other regions of the world seeking to examine the impacts of climate-driven shifts in species distribution on food web structure and ecological integrity.
\end{abstract}




\section{ACKNOWLEDGEMENTS}

I would like to thank my advisor, Dr. Kelton McMahon for sharing your experience and knowledge and for supporting and guiding me throughout the duration of my time at URI-GSO. I would also like to thank my committee members, Dr. Jeremy Collie and Dr. Scott McWilliams, for sharing their expertise and for providing helpful feedback. I am also grateful for the financial support I received through the URI-GSO fish trawl assistantship during my time at URI-GSO. This work was funded through the URI Council for Research and the TNC-URI Student Research Award, for which I am grateful. I would also like to thank fellow McMahon lab members Angela Stahl, Catrina Nowakowski, Joshua Pi, and Dr. Matthew Ramirez for their support and assistance throughout the duration of this thesis. I am also grateful for the guidance and assistance I received from Joseph A. Langan who will be a co-author on this manuscript.

I would also like to acknowledge and thank Capt. Rick Bellavance of Priority Fishing Charters for his assistance in sample collections. I also want to acknowledge the help of Christopher Mayer, Sierra Gray, Chloe Gilligan, and Devin Hennigan for sample preparation and of Rick McKinney of the Atlantic Coastal Environmental Sciences

Division of the Environmental Protection Agency for bulk stable isotope analysis assistance.

Last but not least, I would like to thank my family, friends, and partner for their support and understanding throughout the duration of my thesis work. 


\section{PREFACE}

This thesis has been prepared in manuscript format to meet the criteria set by the Graduate School of the University of Rhode Island. 


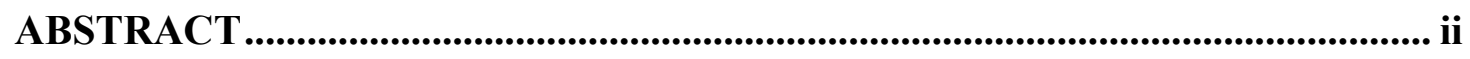

ACKNOWLEDGMENTS ....................................................................................... iii

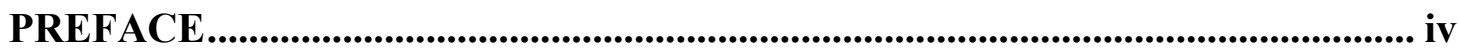

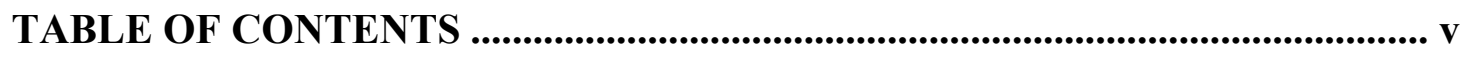

LIST OF TABLES ........................................................................................... vi

LIST OF FIGURES ......................................................................................... vii

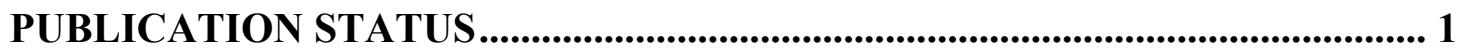

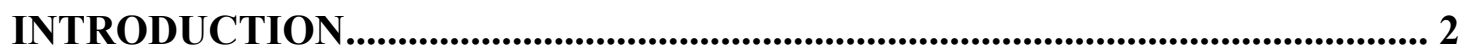

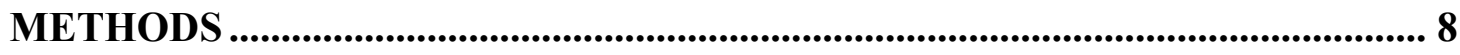

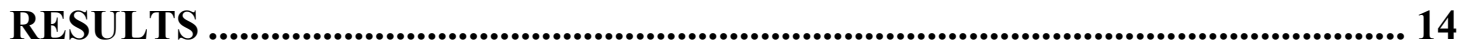

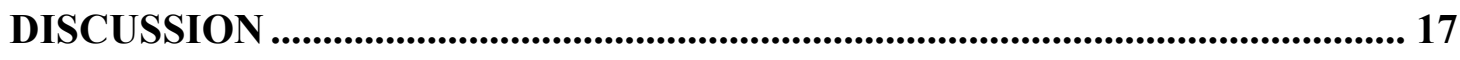

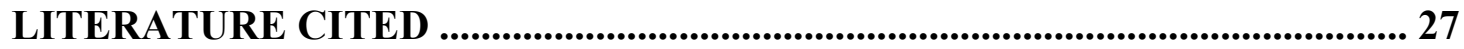




\section{LIST OF TABLES}

TABLE

PAGE

Table 1. Levin's standardized index based on diet of Atlantic cod and black sea bass in winter and summer in Narragansett Bay (NB) and Block Island

Table 2. Linear regression model outputs and post-hoc test results for ANOVA, MANOVA, and ANCOVA

Table S1. Frequency of occurrence (\%) of prey items in diet of Atlantic cod and black sea bass in winter and summer in Narragansett Bay (NB) and Block Island (BI) 36

Table S2. Proportion of total wet weight (\%) of prey items in diet of Atlantic cod and black sea bass in winter and summer in Narragansett Bay (NB) and Block Island (BI).

Table S3. Individual black sea bass specimen data including location and season of capture, total length, sex, bulk $\delta^{15} \mathrm{~N}$ and bulk $\delta^{13} \mathrm{C}$ 38

Table S4. Individual Atlantic cod specimen data including location and

season of capture, total length, sex, bulk $\delta^{15} \mathrm{~N}$ and bulk $\delta^{13} \mathrm{C}$

Table S5. Individual Atlantic cod and black sea bass data for each of the 14

amino acids sampled for $\delta^{15} \mathrm{~N}$ CSIA-AA 40 


\section{LIST OF FIGURES}

FIGURE

PAGE

Figure 1. Map of the Northeast US Shelf showing catch of black sea bass in the NEFSC fall trawl survey between 1970-1974 in blue and 2015-2019 in red. Inset of sampling locations at NB (Narragansett Bay) and BI (Block Island) (Northeast Fisheries Science Center, 2020: Fall Bottom Trawl Survey)

Figure 2. Stomach content analysis for Atlantic cod and black sea bass in winter and summer at Block Island and Narragansett Bay presented as proportion of total wet weight.

Figure 3. Predator feeding strategy and prey importance for Atlantic cod and black sea bass (BSB) at Block Island (BI) and Narragansett Bay (NB) represented as the frequency of prey occurrence and the proportion of the total wet weight made of up that prey item

Figure 4. Standard ellipse area (SEA) analysis of overlap between bulk isotope data for Atlantic cod (orange) and black sea bass (cyan) in winter at NB (A, open circles) and summer at BI (B, closed circles). 44

Figure 5. $\delta^{15} \mathrm{~N}$ values for glutamic acid (glu) and phenylalanine (phe) analyzed with CSIA-AA for Atlantic cod and black sea bass muscle in winter and summer. All Atlantic cod samples are from BI while summer black sea bass samples are from BI and winter samples are from NB. 
Figure 6. Trophic position as calculated by CSIA-AA of Atlantic cod (blue) and black sea bass (orange) in summer (filled bars) and winter (unfilled bars). All Atlantic cod samples are from BI while summer black sea bass samples are from $\mathrm{BI}$ and winter samples are from NB 46

Figure 7. Trophic position compared with fish total length for Atlantic cod (orange) and black sea bass (cyan) in summer (closed circles) and winter (open circles). All Atlantic cod samples are from BI while summer black sea bass samples are from BI and winter samples are from NB. 47 Figure 8. Count of cancer crabs (red) and black sea bass (blue) caught in the URIGSO fish trawl survey 1959-2019 48

Figure S1. Result of the Bayesian standard ellipse area estimate of overlap of bulk isotope data for Atlantic cod and black sea bass (BSB). (A) The proportion of the Cod ellipse overlapping the BSB ellipse in winter, (B) The proportion of the BSB ellipse overlapping the Cod ellipse in winter, (C) The proportion of the Cod ellipse overlapping the BSB ellipse in summer, (D) The proportion of the BSB ellipse overlapping the Cod ellipse in summer

Figure S2. $\delta^{15} \mathrm{~N}$ values for all 14 amino acids analyzed with CSIA-AA for Atlantic cod (orange) and black sea bass (cyan) muscle in winter (open circles) and summer (closed circles).... All Atlantic cod samples are from BI while summer black sea bass samples are from $\mathrm{BI}$ and winter samples are from $\mathrm{NB}$ 50 


\section{PUBLICATION STATUS}

This manuscript is being prepared for submission to Marine Ecology Progress Series. 


\section{INTRODUCTION}

Interspecific competition can have a variety of consequences for competing species including altering their access to prey and habitat, changes in body condition, and shifts in population abundance and distribution (Overholtz and Tyler 1986; Drinkwater 2005). For example, in the northwest Atlantic the decline of top predator gadid populations due, in large part, to overharvesting allowed for a competitive release of elasmobranchs, which increased in abundance with the decrease in competition for shared resources (Fogarty and Murawski 1998). Characterizing competitive interactions of commercially important top predators has implications for our understanding of both fundamental ecological questions of population dynamics and applied questions of effective management of marine resources under changing environmental conditions.

Climate change and the resulting rapid warming of the world's oceans is a powerful driver of new species interactions through the redistribution of predators and prey as well as shifts in habitat availability and changes in consumer physiology (Drinkwater 2005; Fogarty et al., 2008; Rose 2005; Nye et al. 2009). For example, rapid ocean warming on the east coast of the United States has created a new ecological interaction in southern New England (SNE) waters between two commercially important, upper trophic level predators, as the abundance of the black sea bass (Centropristis striata) has increased in the home range of the iconic Atlantic cod (Gadus morhua) (NEFSC 2020). As top predators, both of these species play important ecological roles as top-down drivers of North Atlantic ecosystem structure and competitive interactions between these species could alter the relationships they have within the ecosystem (Fogarty and Murawski 1998; Link et al. 2008; Steneck 2004). Furthermore, both the 
black sea bass and the Atlantic cod have valuable commercial and recreational fisheries that could be affected by new competitive interactions, which would need to be taken into consideration when developing effective management strategies (Shepherd 1991; NMFS 2018).

Black sea bass have been historically sparsely distributed in SNE waters, but over the last few decades have become more abundant in the region (Fig. 1; NEFSC 2020). From 2010 to 2015 alone, the estimated spawning stock biomass of black sea bass increased from 30.7 million lbs. to 48.9 million lbs. in the management area between Cape Hatteras, NC and Cape Cod, MA (NEFSC 2012, 2017). Meanwhile, populations of Atlantic cod, at the southern extent of their native range in SNE, are at historic lows in the Northwest Atlantic due to overfishing and environmental stressors, such as rapid ocean warming (Myers et al 1996; Fogarty et al. 2008). Both species prefer similar habitats with hard-bottomed substrates and are often found on artificial reef structures (Reubens 2013; Steimle 1996). Additionally, the black sea bass is thought to inhabit shallow, coastal waters in summer, and move offshore to deeper water in the MidAtlantic Bight region while SNE cod seasonal movements are not well understood (Musick and Mercer 1977; BOEM 2020). With black sea bass becoming more abundant in SNE, there is growing concern about the potential ecological and economic impacts of competition between Atlantic cod and black sea bass given their increasing overlap, both spatially and temporally, in SNE marine ecosystems (NEFSC, 2020).

According to Link and Auster (2002), in order to infer that interspecific competition is occurring, there are distinct requirements that must be assessed, including: overlap both spatially and temporally between two potential competitors, overlapping 
resource utilization patterns for a shared resource, and resulting opposing population trajectories (Link and Auster, 2002). Though the cod and black sea bass interaction is a new developing one, we know that these species have the potential to shared similar realized ecological niches. They now overlap both spatially and temporally, utilizing the same demersal habitat, and are experiencing opposing populations trajectories in SNE. However, it is unclear how much overlap there is in their resource utilization patterns and specifically their diet and trophic ecology. In SNE, Atlantic cod are upper trophic level predators that feed on cancer crabs, herring, and to a lesser extent, other fish species and the proportion of each of these diet items change seasonally (Link and Garrison, 2002). While little is known about the seasonal diet and foraging ecology of black sea bass in SNE, in their historic home range of the Mid Atlantic Bight region, black sea bass are also generalist, upper trophic level predators and feed on fishes as well as amphipods, crabs, shrimp, and other epibenthic fauna (NEFSC 2017). Diet and trophic ecology are key axes of ecological niche space and can serve as important indicators of resource utilization patterns driving competitive interactions (Alley 1982; Chase and Leibold 2003). Specifically, the competitive exclusion principle suggests that overlap between the two species may exacerbate the population decline in cod as they compete for shared resources or will cause a diversification of the species' realized ecological niches (Hutchinson 1957; Hardin 1960). Assessing dietary and trophic niche overlap between Atlantic cod and black sea bass in SNE is critical to understanding the current overlap in resource utilization and thus the potential for competitive interaction between these two top predators under growing climate-change driven shifts in ecological interactions. 
There are a number of useful analytical tools to assess dietary and trophic niche, from stomach-content analysis and bulk stable isotope analysis to recent developments in compound specific stable isotope analysis of amino acids (CSIA-AA), each with their own strengths and limitations. Stomach-content analysis has been used for centuries to understand species-level diet information (Hyslop 1980). While valuable for the level of taxonomic detail it provides and the ease of comparison between the species in this study, stomach-content analysis only offers a short snapshot of diet in time and is biased towards items that are slower to digest (Jackson and Ryan, 1986; Jackson, Duffy, and Jenkins 1987). It can also be challenging to put upper trophic level, generalist predator diet into the greater food web context without doing the same for all the prey items throughout the entire food web (Post, 2002).

Stable isotope analysis (SIA) complements stomach-content analysis by providing a temporally integrated signal of consumer trophic position and supporting baseline biogeochemical cycling within a food web (Michener and Kaufman 2007). Bulk tissue $\delta^{13} \mathrm{C}$ values change minimally as organic matter moves through a food web via trophic transfers and can be used to glean information about primary production at the base of the food web (Peterson and Fry, 1987). Meanwhile, $\delta^{15} \mathrm{~N}$ values can provide information regarding changes in the sources and cycling of nitrogen in an ecosystem via baseline biogeochemical cycling and an organisms' trophic position (Peterson and Fry 1987; Cifuentes et al. 1988; Goering et al. 1990). Together, these metrics provide food web structure context to individual dietary data from stomach-content analysis. However, it can be difficult to tease apart the relative impact of changes in trophic dynamics versus changes at the base of the food web on consumer bulk tissue isotope values (Post, 2002), 
which paved the way for recent advances in the isotope analysis of individual compounds to study foraging ecology (Ohkouchi et al. 2017; Close 2019).

Compound-specific isotope analysis of amino acids (CSIA-AA) provides a greater level of detail about the metabolic history of how organisms acquire, modify, and allocate resources than traditional bulk tissue SIA. (Ohkouchi et al. 2017). The power of this approach lies in the differential isotope fractionation of individual amino acids (reviewed in McMahon and McCarthy 2016). For instance, a subset of amino acids termed "source" amino acids (e.g., phenylalanine [Phe]), show minimal isotope fractionation between diet and consumer, so the isotopic signatures created by primary producers are passed on to consumers virtually unmodified. $\delta^{15} \mathrm{~N}$ values of source amino acids provide a record of the nitrogen isotope baseline of the food web supporting that system, which can be used to examine baseline biogeochemical cycling (Sherwood et al. 2011; Vokhshoori and McCarthy 2014) and assess consumer foraging location across isoscapes (Dale et al. 2011; Popp et al. 2007). Another subset of amino acids, termed "trophic" amino acids (e.g., glutamic acid [Glu]), undergo significant isotope fractionation during trophic transfers. Together, trophic and source amino acid $\delta^{15} \mathrm{~N}$ values can provide an estimate of both the baseline nitrogen isotope values of the food web and the target organism's trophic position that is internally indexed to the baseline (Chikaraishi et al. 2009; Nielsen et al. 2015; Ishikawa 2018). Characterizing consumer foraging ecology and trophic dynamics to better constrain isotopic niche is valuable for better characterizing consumer dietary and trophic niche within the context of potential interspecific competition. 
Using a multi-metric approach of stomach-content analysis, bulk SIA and CSIAAA, the goal of this study is to understand the seasonal diet and trophic ecology of Atlantic cod and black sea bass in SNE in order to quantify climate-induced resource use overlap. Given that black sea bass have only recently arrived in SNE and their populations are still growing, we hypothesize that Atlantic cod and black sea bass in SNE will strongly overlap in realized ecological niche: 1) consuming diets that strongly overlap, consisting predominately of crabs, shrimps, amphipods, and other epibenthic fauna consistent with diet profiles from their historic ranges, 2) sharing a similar trophic position and feed in food webs with the same baseline production, indicating potential ecological niche overlap, as determined by bulk SIA and CSIA-AA, and 3) showing seasonal shifts in baseline isotope values reflecting similar seasonal shifts in foraging ecology. However, if their ecological interactions are more established than we predict, we may see evidence of niche diversification in the form of divergence in diet and trophic dynamics away from dietary patterns in their historic ranges as a coexistence strategy under increasing competition (Hardin 1960). Understanding dynamics of this new ecological interaction will lead to a more holistic understanding of future ecological trajectories of both species and help better predict the top-down impacts that future competitive interactions between these species may have on ecosystem structure and function. 


\section{METHODS}

Sample site and collections:

Atlantic cod and black sea bass samples were collected from Narragansett Bay and nearshore sites in coastal southern Rhode Island waters from winter 2018 and 2019 as well as summer of 2019 in order to characterize seasonal variation in diet and trophic niche. Narragansett Bay (NB) fish samples were collected within Narragansett Bay, RI $\left(41^{\circ} 26^{\prime} \mathrm{N}, 71^{\circ} 25^{\prime} \mathrm{W}\right)$ (max water depth $\left.20-25 \mathrm{~m}\right)$ via established fish trawl surveys through the University of Rhode Island Graduate School of Oceanography (URI-GSO) (Collie et al. 2008) and Rhode Island Department of Environmental Management (RIDEM) (RI-DEM, 2020) (Fig. 1). Here we describe winter samples as occurring in November through March and summer samples occurring June through September. Nearshore fish samples were collected off Block Island (BI), RI, including Cox Ledge $\left(41^{\circ} 2^{\prime} \mathrm{N} 71^{\circ} 5^{\prime} \mathrm{W}\right.$ and $\left.41^{\circ} 4^{\prime} \mathrm{N} 71^{\circ} 2^{\prime} \mathrm{W}\right), 14 \mathrm{~km}$ offshore of Narragansett Bay (max water depth $45 \mathrm{~m}$ ) via rod and reel through partnerships with regional recreational fishing charters. Samples were collected during both winter and summer in order to characterize seasonal changes in diet that are thought to occur for SNE cod (Link 2002). Samples were collected from both NB and BI in order to characterize diet and trophic dynamics during potential inshore and offshore movements of black sea bass seasonally (Musick and Mercer 1977). Atlantic cod collections included: 35 samples from BI in summer, 18 samples from $\mathrm{BI}$ in winter, 11 samples from NB in winter, and 3 samples from NB in summer. Black sea bass collections included: 22 samples from BI in summer, 22 samples from NB in summer, and 25 samples from NB in winter. Because no samples were caught at BI in winter for black sea bass and few samples were collected at NB in 
summer for Atlantic cod, indices comparing species, season, and location were only assessed for BI summer and NB winter samples. All fish were frozen upon capture and were later thawed for tissue collection and stomach-content analysis.

Stomach-content analysis:

Stomach content analysis followed established RI-DEM protocols (Christine Denisovich, pers. comm.). Briefly, total length and sex of each specimen was recorded, intact stomachs were removed and weighed, and prey items in the stomachs were identified to the lowest possible taxonomic group and enumerated. Removed prey items were grouped by species and recorded as wet weight, along with empty stomachs. The carapace width of intact individuals of the dominant prey items (cancer crabs) was also recorded. Mean carapace width of cancer crab prey in the stomachs of Atlantic cod and black sea bass were compared with a Student's t-test.

The relative contribution of each prey item to the total diet as wet weight and the frequency of occurrence of that diet item were calculated in order to assess dietary overlap in prey composition between Atlantic cod and black sea bass.

Percent weight: $\% \mathrm{~W}=\frac{\text { weight of individuals in a prey category }}{\text { total weight of prey items across all prey categories }} \quad$ eq. 1.

Frequency of occurrence: $\% \mathrm{FO}=\frac{\# \text { of stomachs with a certain prey item }}{\text { total } \# \text { of stomachs that were not empty }} \cdot 100 \quad$ eq. 2 .

The percent weight vs. frequency of occurrence were plotted to illustrate the dominant prey items, with dietary items closer to $100 \%$ occurrence and $100 \%$ abundance considered dominant prey items (Costello 1990). Levins's standardized measure of dietary breadth $\left(\mathrm{B}_{\mathrm{A}}\right)$ was calculated as a means of understanding SNE Atlantic cod and black sea bass dietary niche diversity (Levins 1968): 


$$
B_{A}=\frac{\left(\frac{1}{\sum P i^{2}}-1\right)}{(n-1)}
$$

eq. 3 .

where $\mathrm{B}_{\mathrm{A}}$ is the Levin's standardized index of dietary breadth, Pi is the proportion of prey item " $\mathrm{i}$ " in the diet, and $\mathrm{n}$ is the total number of prey items (Levins, 1968). This standardized metric provides an index of dietary or niche breadth, ranging from 0 as a very narrow dietary niche and 1 as a broad dietary niche (Levins, 1968).

The Morisita- Horn index (Smith and Zaret, 1982), a measure of dietary overlap between Atlantic cod and black sea bass, was calculated in order to compare changes in dietary overlap. This metric provides a measure of dietary overlap ranging from 0 indicating minimal to no overlap and 1 indicating high overlap:

$$
C 1=\frac{2 \sum_{i=1}^{r} P 1 i P 2 i}{\sum_{i=1}^{r} P 1 i^{2}+\sum_{i=1}^{r} P 2 i^{2}}
$$

where $\mathrm{P}_{1 \mathrm{i}}$ is the proportion of the $\mathrm{i}^{\text {th }}$ diet item consumed by predator $1, \mathrm{P}_{2 \mathrm{i}}$ is the proportion of the $\mathrm{i}^{\text {th }}$ diet item consumed by predator 2 , and $\mathrm{r}$ is the total number of diet items (Smith and Zaret, 1982).

Bulk isotope analysis:

White muscle from the dorsal surface for each fish specimen was frozen for 24 hours at $-20^{\circ} \mathrm{C}$, freeze-dried in a Labconco Freezone 2.5 freeze-dryer for 72 hours, and homogenized with a mortar and pestle. Homogenized white muscle samples were subdivided for bulk SIA (this section) and CSIA-AA (next section). No lipid corrections were applied to prey $\delta^{13} \mathrm{C}$ values because muscle samples had weight percent $\mathrm{C}: \mathrm{N}$ ratios (<3.5), indicating negligible lipid contents (Post et al., 2007). For bulk SIA, approximately $1 \mathrm{mg}$ of freeze-dried and homogenized white muscle samples were placed 
into tin capsules and analyzed for bulk stable carbon and nitrogen isotope values on an Elementar Vario Micro / Isoprime 100 at the Atlantic Coastal Environmental Sciences Division of the Environmental Protection Agency. Multiple aliquots of a working standard were run along with samples to correct for instrument drift. The accuracy of the measurements was ensured by running a cysteine standard of known isotopic value with samples and working standard. All isotope values were recorded as $\delta$-values in per mil units (\%) relative to atmospheric $\mathrm{N}_{2}$ for nitrogen and Vienna PeeDee Belemnite for carbon. Sample precision (SD) was $0.27 \pm 0.23 \%$ for $\delta^{15} \mathrm{~N}$ and $0.18 \pm 0.07 \%$ for $\delta^{13} \mathrm{C}$. Standard-corrected bulk $\delta^{13} \mathrm{C}$ and $\delta^{15} \mathrm{~N}$ values were compared between species for BI summer and NB winter using a MANOVA with a post hoc test performed on each response variable using Tukey HSD post-hoc test.

In order to understand the isotopic niche width and overlap of SNE Atlantic cod and black sea bass, the standard ellipse area (SEA) of the bivariate plot of $\delta^{13} \mathrm{C}$ and $\delta^{15} \mathrm{~N}$ values was calculated for each species using the R package SIBER (Jackson et al. 2011). Bivariate isotope data have been described as indicating an organism's isotopic niche, where $\delta^{13} \mathrm{C}$ and $\delta^{15} \mathrm{~N}$ values indicate both "bionomic - resource utilization" and "scenopoetic - bioclimatic" aspects of the niche (Hutchinson 1978; Newsome et al. 2007). Calculating the area of this "niche" provides a proxy for niche width and breadth and we can calculate the overlap of the niche space between our target species in order to understand overlap in resource utilization patterns (Jackson et al. 2011). Compound-specific isotope analysis:

Approximately 5mg of freeze-dried, homogenized white muscle tissue for each sample was acid hydrolyzed in $0.5 \mathrm{~mL}$ of $6 \mathrm{~N}$ hydrochloric acid at $110^{\circ} \mathrm{C}$ for 20 hours to 
produce free amino acids (Gehrke et al., 1985). 5ul of Nor-leucine (with a known $\delta^{15} \mathrm{~N}$ value) was added to each sample as an internal calibration standard prior to derivatization. The hydrolysates were evaporated to dryness under a gentle stream of nitrogen gas. The acid hydrolyzed samples, as well as a mixed amino acid standard of known $\delta^{15} \mathrm{~N}$ value and a working cyanobacteria lab standard of assumed value from hundreds of repeat measurements in multiple independent laboratories, were derivatized to N-trifluoroacetic acid isopropyl esters according to Silfer et al. (1991) as modified by McMahon et al. (2010). Derivatized samples were dissolved in ethyl acetate and injected on column in splitless mode at $240^{\circ} \mathrm{C}$. Individual amino acids were separated on a BPX5 column (60m length, $0.32 \mathrm{~mm}$ ID, $1 \mu \mathrm{m}$ film thickness) in a Thermo Trace 1310 gas chromatograph (GC) and analyzed on a Finnegan Delta V Plus Isotope Ratio Mass Spectrometer (IRMS) interfaced to the gas chromatograph (GC) through a GC-IsoLink II, oxidation/reduction furnace $\left(1000^{\circ} \mathrm{C}\right)$, and liquid nitrogen cold trap at the University of Rhode Island - Graduate School of Oceanography.

Samples were analyzed in triplicate and the mixed amino acid standard and working lab standard were run every two samples to correct for potential kinetic isotope fractionation during the derivatization process (Yarnes and Herszage 2017). The variability reported for $\delta^{15} \mathrm{~N}$ value of each AA measured (Table S3) therefore represents the analytical variation for $\mathrm{n}=3$ replicate GC-C-IRMS measurements. The long-term $\delta^{15} \mathrm{~N}$ reproducibility of the working cyanobacterial laboratory standard, $\pm 0.3 \%$, provides an estimate of full protocol reproducibility (replicate hydrolysis, wet chemistry, and analysis) (calculated as the long-term SD across $>100$ separate full analyses, averaged across all individual AAs). Measured amino acids were classified as trophic amino acids - 
Glu, aspartic acid (Asp), alanine (Ala), leucine (Leu), isoleucine (Ile), proline (Pro), and valine (Val), source amino acids - methionine (Met), lysine (Lys), and Phe, and metabolic amino acids - glycine (Gly), serine (Ser), and threonine (Thr) according to McMahon and McCarthy (2016). The $\delta^{15} \mathrm{~N}$ Glu and $\delta^{15} \mathrm{~N}$ Phe values (our representative trophic and source amino acids) compared between species for NB winter and BI summer samples using a two-way ANOVA and Tukey HSD post-hoc test.

Trophic positions of Atlantic cod and black sea bass were calculated using a $\mathrm{TP}_{\text {CSIA }}$ approach that is internally indexed to the $\delta^{15} \mathrm{~N}$ baseline:

$$
\mathrm{TP}=1+\left(\frac{\delta^{15} N_{G l u}-\delta^{15} N_{P h e}-\beta}{T D F_{G l u-P h e}}\right)
$$

where $\delta^{15} \mathrm{~N}_{\mathrm{Glu}}$ and $\delta^{15} \mathrm{~N}_{\mathrm{Phe}}$ represent the nitrogen isotope ratios in fish tissue samples for Glu (a trophic amino acid) and Phe (a source amino acid), $\beta$ represents the difference in the Glu and Phe nitrogen isotope values in marine microalgae $(2.9+/-1.9 \%$ Nielsen et al. 2015), and $\mathrm{TDF}_{G \mathrm{Gl}-\mathrm{Phe}}$ is the difference in trophic discrimination factors $(6.3+/-0.35 \%$ ) for Glu and Phe (Nielsen et al. 2015). The error was propagated through the trophic position calculation using R package "propagate". TP CSIA were compared between species and seasons and with fish total length as a covariant using an ANCOVA and Tukey's HSD post-hoc test. 


\section{RESULTS}

Stomach content analysis:

Decapod crustaceans were the dominant prey item, by frequency of occurrence and percent wet weight, in both Atlantic cod and black sea bass stomachs (Fig. 2; Table S1, S2). For Atlantic cod, decapod crustaceans occurred in $\geq 89 \%$ of stomachs across locations and seasons. Decapod crustaceans were similarly dominant by frequency of occurrence ( $\geq 82 \%$ ) in black sea bass across seasons and locations (Table S1). Decapod crustaceans also made up the bulk of the total stomach wet weight for Atlantic cod and black sea bass in the study, making up $\geq 72 \%$ of Atlantic cod and $\geq 79 \%$ of black sea bass stomach wet weight across seasons and locations (Fig. 2; Table S2).

Jonah crabs (Cancer borealis) and rock crabs (Cancer irroratus) (henceforth referred to as "cancer crabs") were the dominant type of decapod crustacean found in Atlantic cod and black sea bass stomachs occurring in $\geq 65 \%$ of cod and black sea bass stomachs across most locations and seasons, though only occurring in $18 \%$ of summer black sea bass samples from NB (Table S1). Cancer crabs also made up the bulk of the total stomach wet weight for Atlantic cod and black sea bass in the study, making up $\geq 72 \%$ of Atlantic cod stomach wet weight across most seasons and locations, though they only made up $13 \%$ of the wet weight for summer cod at NB (Fig. 2; Table S2). Meanwhile for black sea bass, cancer crabs made up $\geq 79 \%$ of the wet weight across most locations and seasons, but only $20 \%$ of the wet weight at NB in summer (Fig. 2; Table S2). Using the Costello (1990) method of plotting the percent weight and frequency of occurrence together (Fig. 3; Table S1, S2) it is clear that Atlantic cod and black sea bass have a highly selective diet focused on the dominant prey item of cancer crab in 
Narragansett Bay in winter and Block Island in summer. Carapace width of cancer crabs in stomachs ranged from $8.6 \mathrm{~mm}$ to $51.1 \mathrm{~mm}$ for Atlantic cod and from $9.1 \mathrm{~mm}$ to $58.9 \mathrm{~mm}$ for black sea bass. There was no significant difference between the size of cancer crabs in the stomachs of Atlantic cod $(25.3 \mathrm{~mm} \pm 9.4 \mathrm{SD})$ and black sea bass $(29.0 \mathrm{~mm} \pm 10.9 \mathrm{SD})$ (Student's t test, $\mathrm{p}>0.05$ ).

Though Atlantic cod and black sea bass both show strong overlap in a diet made up of decapod crustaceans, most specifically cancer crabs, other diet items varied in frequency and abundance between Atlantic cod and black sea bass. In Atlantic cod, fishes were a prominent diet item while in black sea bass, other non-decapod crustacean invertebrates were more common. Atlantic cod consumed more fish in winter $(19 \%$ and $20 \%$ by wet weight; $20 \%$ and $50 \%$ by frequency of occurrence) than in summer $(0 \%$ and $1 \%$ by wet weight; $0 \%$ and $7 \%$ by frequency of occurrence) (Fig. 2; Table S1, S2). Black sea bass consumed little fish across seasons and locations, occurring in only $0-13 \%$ of stomachs and making up $0-10 \%$ of the total wet weight (Fig. 2; Table S1, S2).

Both Atlantic cod (Levin's index of standardized niche breadth $=0.01)$ and black sea bass (0.04) at BI in summer as well as black sea bass at NB in winter (0.04) had very narrow dietary niche breadths (Table 1). While neither species had a dietary niche breadth above 0.5 , both species showed broader dietary niches at NB, in winter $(0.21)$ and summer (0.33) for cod and in summer only (0.43) for black sea bass. Calculations of the Morisita-Horn index indicate high dietary overlap (0.99) between Atlantic cod and black sea bass at BI in summer and moderate overlap (0.34) between Atlantic cod and black sea bass at NB in winter.

Bulk isotope analysis: 
There were some significant differences in both $\delta^{13} \mathrm{C}$ and $\delta^{15} \mathrm{~N}$ values between species and seasons (Fig. 4; Table S3, S4). SEA-C niche breadth was larger for both Atlantic cod (1.42\%o) and black sea bass $(0.98 \%)$ in winter at NB than it was for both Atlantic cod (0.67\%o) and black sea bass (0.31\%o) in summer at BI (Fig. 4). The Bayesian metric of Standard Ellipse Area overlap for these species indicates that roughly $30-80 \%$ of the niche area is overlapping at NB in winter compared to $50-85 \%$ of niche area overlap at BI in summer (Fig. 5, S1).

CSIA-AA:

Glu $\delta^{15} \mathrm{~N}$ values were not significantly different among summer Atlantic cod at $\mathrm{BI}$, summer black sea bass in BI, and winter black sea bass in NB, but winter cod in NB had significantly higher Glu $\delta^{15} \mathrm{~N}$ values (ANOVA p<0.05; Table 2) (Fig. 5; Table S5). Phe $\delta^{15} \mathrm{~N}$ values were not significantly different between species in either season but were significantly lower in winter than in summer for both species (ANOVA $p<0.05$; Table 2) (Fig. 5; Table S5). TP CSIA-AA of Atlantic cod (4.1 $\pm 0.09 \mathrm{SD})$ were significantly higher than black sea bass $(3.5 \pm 0.3 \mathrm{SD})$ in winter (ANCOVA $\mathrm{p}<0.05$; Table 2$)$ but not significantly different in summer (cod: $3.5 \pm 0.3 \mathrm{SD}$, black sea bass $3.4 \pm 0.9 \mathrm{SD}$ ) (Fig. 6). There was a significant effect of fish total length on trophic position for Atlantic cod $\left(\mathrm{R}^{2}=0.5\right.$; ANCOVA $\mathrm{p}<0.05$; Table 2$)$ but not black sea bass (Fig. 7). 


\section{DISCUSSION}

Our study found that Atlantic cod and black sea bass in SNE feed at the same trophic position in food webs with the same isotope baseline and show strong dietary selection for cancer crabs, though the strength of the selectivity and thus dietary overlap varies seasonally. We provide multi-faceted evidence of overlap in dietary and trophic niche between Atlantic cod and black sea bass that sets the stage for dietary resource competition as waters continue to warm in SNE, resulting in predicted increases in black sea bass abundance and decreases in cancer crab abundance, the primary dietary target of both species according to our study. Overlap in resource utilization between Atlantic cod and black sea bass has important implications for the ecological trajectory of their shared ecosystem, as important top-down drivers of food web dynamics, as well as for the effective management of their fisheries and the fisheries of their crustacean diets.

As hypothesized, Atlantic cod and black sea bass show strong overlap in realized dietary niche, with both species showing high diet selection for decapod crustaceans (72$98 \%$ of wet weight and 0.34-0.99 in the Morisita-Horn index). While stomach content analysis is inherently a short snapshot of diet, this low trophic level diet selection was corroborated by the low trophic position calculations (3.4-4.1) using CSIA-AA that is internally indexed to the baseline. Previous studies of the diet of black sea bass have indicated that decapod crustaceans make up a large proportion of the diet in the Mid- and South- Atlantic Bights (Sedbery 1988; Steimle 1996) as well as in our study region (Malek 2015). However, previous studies of Atlantic cod diet in SNE two decades ago indicated a more varied and higher trophic level diet, including herring and other fish (Link 2002) compared to the strong selection for cancer crabs that we found now. Studies 
of Atlantic cod diet in the Gulf of Maine did indicate that a diet of fish was less common for inshore cod in Maine bays and coves (Willis 2017). This could mean that cancer crabs are a more important resource for inshore cod, like the subpopulation in our study.

Both Atlantic cod and black sea bass show more diverse diets in winter, with fish and other invertebrates making up 20-30\% by wet weight of cod diet and $20 \%$ of black sea bass diet. This dietary expansion could reflect a shift to alternative diet sources as their primary prey, cancer crabs, exhibit seasonal movements offshore into deeper waters in winter (Truesdale 2019). Alternatively, this diversification of the diet in winter could also be due to a competitive release as many other piscivorous fishes move out of Narragansett Bay in winter, allowing both predators to increase foraging on fish at NB in the winter (Malek 2015). This seemingly broader dietary niche in winter could also be a limitation of the stomach content analysis technique, where selective digestion and rate of metabolism could play a role in which prey items we see seasonally (Hess and Rainwater 1939; Baldwin 1957). However, known shifts in prey movements, coupled with the isotopic niche measurements we observed for NB winter samples being broader than BI summer samples, support the hypothesis that the dietary niche of both species is in fact broader in winter. More research on the movement patterns of key prey items and competitors could help shed light on the relative importance of these potential drivers of winter dietary diversification.

Despite some seasonal variation in overall diet diversity, both Atlantic cod and black sea bass in SNE have highly selective diets focused on cancer crabs in the region. Though both species are considered generalists in terms of their fundamental ecological niches, this high dietary selection indicates that in SNE, both species occupy similar 
narrow realized niche space (Hutchinson 1957; Vandermeer 1972). When coupled with the fact that we found relatively few empty stomachs (26\% for Atlantic cod and $30 \%$ for black sea bass), it suggests that competition between these two species is likely low at the moment due to food not being a limited resource. However, this high diet selectivity for cancer crabs is important to note because it could have implications for how these species respond to future environmental changes that impact their prey sources. Ecological theory dictates that specialists are typically more sensitive to ecological and environmental change than organisms that have more generalist resource utilization patterns (Clavel et al. 2011; Moritz 2013; Menéndez et al. 2006; Lurgi et al. 2012). As such, it is likely that crab population dynamics in the region could play an important role in dictating resource utilization patterns between these species and potentially their population trajectories in SNE. Given their sensitivity to warming waters and increased hypoxia, both predicted to increase over the next century (Cheng et al. 2019), cancer crabs are likely to have high mortality rates as waters in SNE continue to warm (Frederich et al 2009; Deutsch 2015). In order to assess the abundance of the dominant prey item, cancer crabs, and black sea bass through time in Narragansett Bay, count data for both species was queried from the URI-GSO fish trawl survey in Narragansett Bay from 1959 through 2019. The data for both species were plotted together to compare historical and modern population abundance in Narragansett Bay (Fig. 8). There is evidence of declining cancer crab abundance and increased black sea bass abundance since the early 2000s in Narragansett Bay recorded in the survey.

A significant decline in cancer crab abundance in the region, without a corresponding shift in Atlantic cod and black sea bass diet, could exacerbate interactions 
between these consumers through increased competition for limited resources, since the competitive exclusion principle says that two species cannot coexist when competing for limited shared resources (Hardin 1960). Thus, a decline in cancer crab abundance in SNE could potentially cause a decline in populations of cod and black sea bass in the region similar to how declines in key prey items like the copepod Calanus finmarchicus for Atlantic cod larvae in the North Sea has caused recruitment failure for the stock (Beaugrand at al. 2003). Alternatively, since both the Atlantic cod and black sea bass are considered generalist predators, a decline in cancer crabs could cause a niche diversification shift in one or both species to other prey items in the region, which could have cascading consequences for these species and the rest of the food web (Hardin 1960). Furthermore, we do not yet know how shifting diets might affect Atlantic cod and black sea bass themselves, as new diet items may have a difference in caloric value or could require different energy expenditures for capture, which could impact body condition (Graeb et al. 2006; Beaugrand et al. 2003; Beaugrand and Kirby 2010).

The strong dietary selection of Atlantic cod and black sea bass for crabs in SNE could also play a role in the trajectory of the crab population in SNE as well as the fishery that depends on them. All of the cancer crabs found in this study were $10-60 \mathrm{~mm}$ in length and thus are considered juveniles for Jonah crab (Olsen and Stevens 2020). A study of Jonah crab biological characteristics for the Rhode Island Sound illustrate that Jonah crab can be as large as $150 \mathrm{~mm}$ in length in the region, indicating that Atlantic cod and black sea bass in SNE are targeting juveniles of the species though larger crabs are available to them (Truesdale 2018). Interestingly, that study failed to find any juveniles in the region, creating management challenges for identifying important nursery regions (Truesdale 
2018). However, our study clearly shows that juveniles are here in the region given their overwhelming abundance in fish stomachs in this study.

The fact that crabs made up a significant portion of Atlantic cod and black sea bass diet and were all juveniles suggests a potentially high mortality rate on the juvenile life stage of crabs. This pressure on the early life stage could have significant impacts on adult crab population dynamics. For example, in Alaskan waters, increases in groundfish abundance were tied to a similar potential population bottleneck for their preferred prey item, juvenile red king crabs (Bechtol and Kruse 2009; Zheng and Kruse 2006). This predation on juvenile crabs could have important implications for the growing Jonah crab fishery in SNE, with landings of 2-3 million pounds in the 1990's growing to 17 million pounds by 2014 (ASFMC, 2015). Conversely, another important fishery species that has become a concern as black sea bass become more abundant in SNE is the American lobster (Homarus americanus). There is significant research ongoing to effectively manage lobsters, whose populations are crashing in SNE due to ocean warming and disease (Wahle et al. 2015). Fishermen in the region are concerned about the possibility of predation by black sea bass on juvenile lobsters, and some studies did find evidence that this could be the case (McMahan 2017; Saltzberg 2019). However, in our study, no juvenile lobsters were found in the stomachs of any black sea bass or Atlantic cod for that matter. This might suggest that the arrival of black sea bass has not contributed to the decline in lobster in SNE. However, this study was not a comprehensive survey of the entire SNE region, so a region wide survey is likely needed to more definitively conclude whether or not black sea bass are important predators of juvenile lobsters. Lobsters notwithstanding, our study still suggests that predation by cod and black sea bass may 
have important top-down impacts on the trajectories and subsequent management practices of multiple important fisheries in the region.

Though diet is a valuable metric of recent resource utilization patterns, the data can be challenging to interpret in a broader ecosystem or food web dynamic context. The standard ellipse area (SEA) analysis of bivariate isotope data allows us to estimate an organisms' isotopic niche breadth and can tell us about overall resource utilization including diet and habitat - and thus gives us a more integrative understanding of how organisms fit into a food web (Jackson et al. 2011; Newsome et al. 2007). While black sea bass had a notably narrower isotopic niche than Atlantic cod, Bayesian estimates of SEA overlap indicate significant similarity between Atlantic cod and black sea bass isotopic niche at $\mathrm{BI}$ in summer and NB in winter as hypothesized (hypothesis 2 and 3) (Guzzo et al. 2013; Schoener 1968). For both species, the niche width expands in winter relative to summer, likely due to the diversification of diet in both Atlantic cod and black sea bass in winter, as shown in the stomach content data.

In order to better understand the patterns of resource utilization leading to the strong isotope niche overlap, we can explore potential underlying drivers of the isotope variability in Atlantic cod and black sea bass in SNE. For example, there is a seasonal difference in bulk $\delta^{15} \mathrm{~N}$ and $\delta^{13} \mathrm{C}$ values in SNE Atlantic cod bulk isotope values. One explanation for this change in isotope value is a difference in trophic position for Atlantic cod and black sea bass seasonally, which can create a difference of up to $\sim 3-4 \%$ in $\delta^{15} \mathrm{~N}$ value and $0-1 \%$ in $\delta^{13} \mathrm{C}$ value with each additional trophic transfer (Peterson and Fry, 1987). Alternatively, this seasonal change in isotope values could reflect changes in baseline biogeochemical cycling and phytoplankton production dynamics that can alter 
the baseline $\delta^{15} \mathrm{~N}$ and $\delta^{13} \mathrm{C}$ pool that are then subsequently passed through the food web to upper trophic level consumers (Sigman et al. 2009; Sigman et al. 1999; Fry 2002). With bulk SIA, it can be difficult to tease apart the relative impact of changes in trophic dynamics versus changes at the base of the food web on consumer isotope values (Post, 2002). Thus, we used CSIA-AA $\delta^{15} \mathrm{~N}$ values of trophic and source amino acids to tease apart trophic and baseline variation in our consumer tissues (McMahon and McCarthy, 2016).

Both Atlantic cod and black sea bass had similar $\delta^{15} \mathrm{~N}$ values of Phe, a source amino acid that serves as a proxy for the nitrogen isotope baseline, indicating that the two species are likely foraging in food webs with similar baselines in both winter and summer. When put in the context of the strongly overlapping crustacean diets, these results suggest that both Atlantic cod and black sea bass are foraging on the same prey in the same food web, which supports our second and third hypotheses. However, there was a significant shift in both bulk and Phe $\delta^{15} \mathrm{~N}$ value for both species seasonally, with higher $\delta^{15} \mathrm{~N}$ values in summer compared to winter. Oczkowski et al. (2017) showed a similar summer $\delta^{15} \mathrm{~N}$ enrichment and winter $\delta^{15} \mathrm{~N}$ depletion in Narragansett Bay that was hypothesized to be related to changes in production and recycled particulate nitrogen. Thus, it is likely that the observed differences in seasonal and NB/BI $\delta^{15} \mathrm{~N}$ signals in this study are also related to the changes in mixing and subsequent nutrient inputs and availability for Narragansett Bay and Rhode Island Sound. Narragansett Bay and Rhode Island Sound are more well-mixed leading to similar nutrient availability between both locations in winter as opposed to summer where there is a stronger nutrient gradient (with higher levels of nitrate inshore) and less mixing (Chaves 2004; Oczkowski 2017; Rosa 
2020). As such, the similar Phe $\delta^{15} \mathrm{~N}$ values within seasons between our two species indicates that they are likely exhibiting relatively small foraging ranges to maintain similar, local food web baselines and are not foraging across distinctly different habitats in SNE.

While $\delta^{15} \mathrm{~N}$ values for Phe indicate that Atlantic cod and black sea bass are foraging in the same food webs in SNE, Phe and Glu $\delta^{15} \mathrm{~N}$ values together can be used to calculate predators' trophic position that is internally indexed to the baseline (Chikaraishi

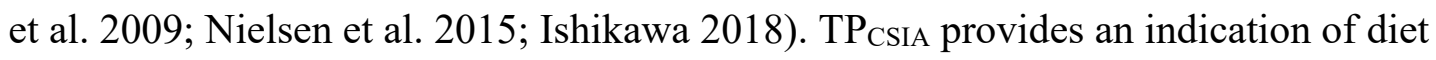
integrated over a longer time period than stomach content analysis can allow us to

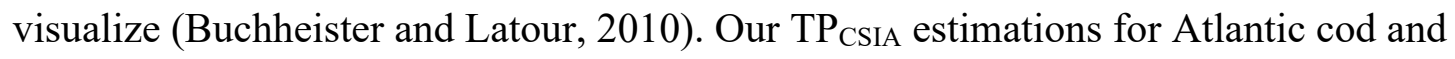
black sea bass indicate that there is strong overlap in trophic position for both species in summer with both species being about trophic level 3.5. While the sample sizes for CSIA-AA analyses were small relative to bulk SIA and stomach content analyses, the patterns we observed corroborate each other, lending confidence to the estimates. For example, this trophic position agrees well with estimates of other crustacean eaters in the region like the smooth dogfish, and summer is when we saw the most diet selectivity of cod and black sea bass on cancer crabs (Malek 2015). In winter, black sea bass remained at trophic level 3.5 while Atlantic cod increased to trophic level 4.1. This increase in trophic position for winter cod makes sense when compared with the diet data that showed an increase in dietary niche in winter due to an increase in consumption of upper trophic level fish (e.g. silver hake [TP 4.2] and red hake [TP 4.3]) (Bowman et al. 2000; Hesler et al. 1995). Meanwhile, winter black sea bass consume more lower trophic level invertebrates in addition to cancer crabs and thus their trophic position remains relatively 
constant. These $\mathrm{TP}_{\mathrm{CSIA}}$ data suggest that the dietary patterns observed in the stomachcontent analyses were longer term, seasonal patterns and not biased by the short snapshot nature of the stomach-content analysis approach. It is also worth noting that our Atlantic cod samples in winter were larger (by total length) than those caught in summer, which has implications for the size of diet items that can potentially be consumed and thus could be the reason for the increased the trophic position of larger Atlantic cod (Cohen et al. 1993; France et al. 1998; Woodward and Hildrew 2002). Our study also focused on adult sizes of both species so juvenile diet has not been taken into account, thus future work could be done to understand the overlap in resource utilization patterns between juvenile cod and black sea bass in SNE.

This multi-metric approach provides a compelling example of how climate change can shape species interactions through species range shifts, changes in population sizes, and shifting prey fields and prey availability. The results of this study indicate a strong overlap in diet, dietary and trophic niche, trophic position, and foraging location between Atlantic cod and black sea bass in SNE waters. This dietary overlap between these two predators has a variety of potential implications for the top-down control on the structure and function of SNE ecosystems as well as the management of fisheries that depend on them. The strong selection of Atlantic cod and black sea bass for cancer crab coupled with the rapidly growing black sea bass population could have ecological and fisheries management implications for the burgeoning Jonah crab fishery. A decline in cancer crab abundance could have implications for Atlantic cod and black sea bass, which this study shows to have highly selective crustacean diets. Future research could be 
done to further understand the effect that the seasonal prey and competitor field could have on this interaction between Atlantic cod and black sea bass. 


\section{LITERATURE CITED}

Alley, T.R. (1982). Competition theory, evolution, and the concept of an ecological niche. Acta Biotheoretica, 31,165-179.

Atlantic States Marine Fisheries Commission. 2015. Interstate Fishery Management Plan for Jonah Crab.US Department of Commerce. Retrieved from http://www.asfmc.org/uploads/file//56e1f58cJonahCrabInterstateFMP_Aug2015. pdf

Baldwin, N.S. (1957). Food consumption and growth of brown trout at different temperatures. Trans. Am. Fish. Soc. 86, 323-328.

Beaugrand, G., \& Kirby, R. R. (2010). Climate, plankton and cod. Global Change Biol., 16(4), 1268-1280.doi:10.1111/j.1365-2486.2009.02063

Beaugrand, G., Brander, K., Lindley, J.A., Souissi, S. and Reid, P.C. (2003) Plankton effect on cod recruitment in the North Sea. Nature., 426, 661-664.

Bechtol, W.R., Kruse, G.H. (2009). Reconstruction of historical abundance and recruitment of red king crab during 1960-2004 around Kodiak, Alaska. Fish. Res., 100: 86-98.

BOEM 2020. Movement Patterns of Fish in Southern New England (AT-19-08). Environmental Studies Program. Retrieved from https://www.boem.gov/sites/default/files/documents/environment/environmentalstudies/Movement $\% 20$ Patterns $\% 20$ of $\% 20$ Fish $\% 20$ in $\% 20$ Southern $\% 20 \mathrm{New} \% 20 \mathrm{E}$ ngland_0.pdf.

Bowman, R.E., C.E. Stillwell, W.L. Michaels and M.D. Grosslein, 2000. Food of northwest Atlantic fishes and two common species of squid. NOAA Tech. Memo. NMFS-NE 155, $138 \mathrm{p}$.

Buchhesiter, A., \& Latour, R.J. (2010). Turnover and fractionation of carbon and nitrogen stable isotopes in tissues of a migratory coastal predator, summer flounder (Paralichthys dentatus). Can. J. Fish. Aquat. Sci., 67(3): 445-461. Doi: 10.1139/F09-196.

Chase, J. M., \& Leibold, M. A. (2003). Ecological niches: linking classical and contemporary approaches. University of Chicago Press.

Chaves, J. E. (2004). "Potential use of nitrogen-15 to assess nitrogen sources and fate in Narragansett Bay". Dissertations and Master's Theses (Campus Access). Paper AAI3135896. https://digitalcommons.uri.edu/dissertations/AAI3135896.

Cheng L., Abraham J., Hausfather Z., Trenberth K.E. (2019). How fast are the oceans warming? Science., 363(6423):128-129. DOI: 10.1126/science.aav7619.

Chikaraishi, Y., Ogawa, N. O., Kashiyama, Y., Takano, Y., Suga, H., Tomitani, A., Miyashita, H., Kitazato, H., \& Ohkouchi, N. (2009). Determination of aquatic food-web structure based on compound-specific nitrogen isotopic composition of amino acids. Limnol. Oceanogr-Methods., 7(11):740-750. doi:

10.4319/lom.2009.7.740. 
Cifuentes, L.A., Sharp, J.H., \& Fogel, M.L. (1988). Stable carbon and nitrogen isotope biogeochemistry in the Delaware Estuary. Limnol. And Oceanogr., 33:1102-1115.

Clavel, J., Julliard, R., \& Devictor, V. (2011). Worldwide decline of specialist species: toward a global functional homogenization?. Front. Ecol. Environ., 9(4), 222-228.

Close, H. G. (2019). Compound-specific isotope geochemistry in the ocean. Annu. Rev. Mar. Sci., 27-56. https://doi.org/10.1146/annurev-marine-121916-063634

Cohen, J.E., Pimm, S.L., Yodzis, P., Saldana, J. (1993). Body sizes of animal predators and animal prey in food webs. J. Anim. Ecol. 62, 67-78.

Collie, J.S., Wood, A.D., \& Jeffries, H.P. (2008). Long-term shifts in the species composition of a coastal fish community. Can. J. Fish. Aquat. Sci., 65:1352-1365.

Costello, M. J. (1990). Predator feeding strategy and prey importance: a new graphical analysis. J. of Fish Biol., 36(2), 261-263. https://doi.org/10.1111/j.10958649.1990.tb05601

Deutsch, C., Ferrel, A., Seibel, B., Pörtner, H.O., \& Raymond, B.H. (2015). Constraint on Marine Habitats. Science, 348(6239), 1132-1136.

Dale J.J., Wallsgrove N.J., Popp B.N., Holland K.N. (2011). Nursery habitat use and foraging ecology of the brown stingray Dasyatis lata determined from stomach contents, bulk and amino acid stable isotopes. Mar. Ecol. Prog. Ser., 433:221236. https://doi.org/10.3354/meps09171

Drinkwater, K.F. (2005). The response of Atlantic cod (Gadus morhua) to future climate change. ICES. J. of Mar. Sci., 62(7):1327-1337. Doi: 10.1016/j.icesjms.2005.05.015

Fogarty, M. J., \& Murawski, S. A. (1998). Large-scale disturbance and the structure of marine systems: Fishery impacts on Georges Bank. Ecol. Appl., 8(1 SUPPL.), 622. https://doi.org/10.2307/2641359

Fogarty, M., Lewis I., Hayhoe, K., Mountain, D., \& Manning, J. (2008). Potential climate change impacts on Atlantic cod (Gadus morhua) off the northeastern USA. Mitig. Adapt. Strat. Glob. Change., 13:353-466. Doi:10.1007/s11027-007-9131-4

France, R., Chandler, M., Peters, R. (1998). Mapping trophic continua of benthic food webs: body size-delta N15 relationships. Mar. Ecol. Prog. Ser., 174, 301-306.

Frederich, M., O’Rourke, M. R., Furey, N. B., \& Jost, J. A. (2009). AMP-activated protein kinase (AMPK) in the rock crab, Cancer irroratus: An early indicator of temperature stress. J. Exp. Biol., 212(5), 722-730. https://doi.org/10.1242/jeb.021998

Gehrke, C. W., Wall Sr, L. L., Absheer, J. S., Kaiser, F. E., \& Zumwalt, R. W. (1985). Sample preparation for chromatography of amino acids: acid hydrolysis of proteins. J. Accos. Off. Ana. Chem., 68(5), 811-821.

Goering J., Alexander, V., \& Haubenstock, N. (1990). Seasonal variability of stable carbon and nitrogen isotope ratios of organisms in a North Pacific Bay. Estuar. Coast. Shelf. Sci., 30(3):239-260. Doi: 10.1016/0272-7714(90)90050-2. 
Graeb, B. D. S., Mangan, M. T., Jolley, J. C., Wahl, D. H., \& Dettmers, J. M. (2006). Ontogenetic Changes in Prey Preference and Foraging Ability of Yellow Perch: Insights Based on Relative Energetic Return of Prey. T. Am. Fish. Soc., 135(6), 1493-1498. https://doi.org/10.1577/t05-063.1

Guzzo, M. M., Haffner, G. D., Legler, N. D., Rush, S. A., \& Fisk, A. T. (2013). Fifty years later: Trophic ecology and niche overlap of a native and non-indigenous fish species in the western basin of Lake Erie. Biol. Invasions., 15(8), 1695-1711. https://doi.org/10.1007/s10530-012-0401

Hardin, G. (1960). The competitive exclusion principle. science, 131(3409), 1292-1297.

Hesler, T.E., F.P. Almeida and D.E. Waldron, 1995. Biology and fisheries of north-west Atlantic hake (silver hake: M. bilinearis). p. 203-237. In J. Alheit and T.J. Pitcher (eds.) Hake:Biology, fisheries and markets. Chapman \& Hall, London, 478 p.

Hess, A. D., \& Rainwater, J. H. (1939). A Method for Measuring the Food Preference of Trout. Copeia, 1939(3), 154.doi:10.2307/1436810.

Hutchinson GE. (1957). Concluding remarks: Cold Spring Harbor symposium. Quant Biol 22: 415-27.

Hutchinson GE. (1978). An introduction to population biology. New Haven, CT: Yale University Press.

Hyslop, E. J. (1980). Stomach contents analysis - a review of methods and their application. J. Fish. Biol., 17(4), 411-429.

Ishikawa, N.F. (2018). Use of compound-specific nitrogen isotope analysis of amino acids in trophic ecology: assumptions, applications, and implications. Ecol Res., 33:825-837 https://doi.org/10.1007/s11284-018-1616-y

Jackson, A.L., Inger, R., Parnell, A.C., \& Bearhop, S. (2011). Comparing isotopic niche widths among and within communities: SIBER- Stable Isotope Bayesian Ellipses in R. J. Anim. Ecol., 80(3):595-602. Doi: 10.1111/j.1365-2656.2011.01806.x.

Jackson, S. \& Ryan, P. G. (1986). Differential digestion rates of prey by white-chinned petrels Procellaria aequinoctialis. Auk., 103: 617-619.

Jackson, S., Duffy, D. C., \& Jenkins, G. (1987). Gastric digestion in marine vertebrate predators: in vitro standards. Funct. Ecol., 1: 287-291.

Levins, R. (1968). Evolution in changing environments. Princeton University Press, Princeton.

Link, J. S., Bogstad, B., Sparholt, H., \& Lilly, G. R. (2009). Trophic role of Atlantic cod in the ecosystem. Fish and Fisheries, 10(1), 58-87. https://doi.org/10.1111/j.1467-2979.2008.00295.X

Link, J.S. \& Garrison, L.P. (2002). Trophic ecology of Atlantic cod Gadus morhua on the northeast US continental shelf. Mar. Ecol. Prog. Ser., 227:109-123. Doi: $10.3354 /$ meps 227109 .

Lurgi, M., López, B. C., \& Montoya, J. M. (2012). Novel communities from climate change. Philos. T. R. Soc. B., 367(1605), 2913-2922. 
Malek, A. (2015). "An Investigation of the Fisheries Ecosystem Dynamics in Rhode Island's Nearshore Waters" (2015). Open Access Dissertations. Paper 352. https://digitalcommons.uri.edu/oa_diss/352.

McMahan M.D., Sherwood, G.D., \& Grabowski, J.H. (2020). Geographic variation in life-history traits of black sea bass (Centropristis striata) during a rapid range expansion. Front. Mar. Sci., 7:803.

McMahon, K. W., \& McCarthy, M. D. (2016). Embracing variability in amino acid $\delta 15 \mathrm{~N}$ fractionation: mechanisms, implications, and applications for trophic ecology. Ecosphere., 7(12), e01511.

McMahon, K. W., Fogel, M. L., Elsdon, T. S., \& Thorrold, S. R. (2010). Carbon isotope fractionation of amino acids in fish muscle reflects biosynthesis and isotopic routing from dietary protein. J. Anim. Ecol., 79(5), 1132-1141. doi:10.1111/j.1365-2656.2010.01722

Michener, R.H. and Kaufman, L. (2007). Stable Isotope Ratios as Tracers in Marine Food Webs: An Update. In Stable Isotopes in Ecology and Environmental Science (eds R. Michener and K. Lajtha). https://doi.org/10.1002/9780470691854.ch9

Moritz, C., \& Agudo, R. (2013). The future of species under climate change: resilience or decline?. Science., 341(6145), 504-508.

Musick, J.A. \& Mercer, L.P. (1977). Seasonal distribution of black sea bass, Centropristis striata, in the Mid-Atlantic Bight with comments on the ecology and fisheries of the species. Transactions of the Amer. Fish. Soc., 106(1):12-25. Doi: 10.1577/1548-8659(1977)106<12:SDOBSB $>2.0 . C O ; 2$.

Myers, R.A., Hutchings, J.A., \& Barrowman, N.J. (1996). Hypotheses for the decline of cod in the North Atlantic. Mar. Ecol. Prog. Ser., 138:293-308.

National Marine Fisheries Service. 2018. Fisheries Economics of the United States, 2016. U.S. Dept. of Commerce, NOAA Tech. Memo. NMFS-F/SPO-187, 243 p.

Newsome, S.D., Martinez del Rio, C., Bearhop, S., \& Phillips, D.L. (2007). A niche for isotopic ecology. Front. Ecol. Environ., 5:429-436. Doi: 10.1890/060150.1.

Nielsen, J. M., Popp, B. N., \& Winder, M. (2015). Meta-analysis of amino acid stable nitrogen isotope ratios for estimating trophic position in marine organisms. Oecologia., 178(3), 631-642.doi:10.1007/s00442-015-3305-7

Northeast Fisheries Science Center (2020) Fall Bottom Trawl Survey. Retrieved from: https://catalog.data.gov/dataset/fall-bottom-trawl-survey.

Northeast Fisheries Science Center. (2012). 53rd Northeast Regional Stock Assessment Workshop (62nd SAW) Assessment Summary Report. US Dept Commer, Northeast Fish Sci Cent Ref Doc.,12-03; 33. http://www.nefsc.noaa.gov/publications/.

Northeast Fisheries Science Center. (2017). 62nd Northeast Regional Stock Assessment Workshop (62nd SAW) Assessment Summary Report. US Dept Commer, Northeast Fish Sci Cent Ref Doc.,17-01; 37. http://www.nefsc.noaa.gov/publications/. 
Nye, J.A., Link, J.S., Hare, J.A., \& Overholtz, W.J. (2009). Changing spatial distribution of fish stocks in relation to climate and population size on the Northeast United States continental shelf. Mar. Ecol. Prog. Ser., 339:111-129. Doi: 10.3354/ meps08220.

Oczkowski, A., Schmidt, C., Santos, E., Miller, K., Hanson, A., Cobb, D., Krumholz, J., Pimenta, A., Heffner, L., Robinson, S., Chaves, J., \& McKinney, R. (2018). How the distribution of anthropogenic nitrogen has changed in Narragansett Bay (RI, USA) following major reductions in nutrient loads. Estuaries and coasts: journal of the Estuarine Research Federation., 41(8), 2260-2276. https://doi.org/10.1007/s12237-018-0435-2

Ohkouchi, N., Chikaraishi, Y., Close, H. G., Fry, B., Larsen, T., Madigan, D. J., ... \& Ogawa, N. O. (2017). Advances in the application of amino acid nitrogen isotopic analysis in ecological and biogeochemical studies. Organic. Geochem., 113, 150174.

Olsen, N. A., \& Stevens, B. G. (2020). Size at Maturity, Shell Conditions, and Morphometric Relationships of Male and Female Jonah Crabs in the Middle Atlantic Bight. N. Am. J. Fish. Manage., 1-14. https://doi.org/10.1002/nafm.10509

Overholtz W.J. \& Tyler, A.V. (1986). An exploratory simulation model of competition and predation in a demersal fish assemblage on Georges Bank. Trans. Am. Fish. Soc. 115:6, 805-817.

Peterson, B.J. \& Fry, B. (1987). Stable isotopes in ecosystem studies. Ann. Rev. Ecol. Syst., 18(1):293-320.

Popp, B.N., Graham, B.S., Olson, R.J., Hannides C.C.S., Lott, M.J., Lopez-Ibarra G.A., Galvan-Magana, F., \& Fry, B. (2007). Insight into the Trophic Ecology of Yellowfin Tuna, Thunnus albacares, from Compound-Specific Nitrogen Isotope Analysis of Proteinaceous Amino Acids, Terr. Ecol.1:173-190.

Post, D. M., Layman, C. A., Arrington, D. A., Takimoto, G., Quattrochi, J., \& Montaña, C. G. (2007). Getting to the fat of the matter: models, methods and assumptions for dealing with lipids in stable isotope analyses. Oecologia., 152(1), 179189.doi:10.1007/s00442-006-0630

Post, D.M. (2002). Using stable isotopes to estimate trophic position: models, methods, and assumptions. Ecol., 83(3)703-718.

Doi:10.1890/00129658(2002)083[0703:USITET]2.0.CO;2.

Reubens, J. T., Pasotti, F., Degraer, S., \& Vincx, M. (2013). Residency, site fidelity and habitat use of atlantic cod (Gadus morhua) at an offshore wind farm using acoustic telemetry. Mar. Environ. Res., 90, 128-135. https://doi.org/10.1016/j.marenvres.2013.07.001

RI-DEM. (2020). RI-DEM Coastal Trawl Survey. Retrived from: http://www.dem.ri.gov/programs/marine-fisheries/surveys-pubs/coastaltrawl.php/.

Rosa, K. (2020). Coastal Ocean Modeling Across Length Scales: From Estuarine Circulation to Boundary Currents. https://digitalcommons.uri.edu/dissertations/. 
Rose, G. A. (2005). On distributional responses of North Atlantic fish to climate change. ICES J. Mar. Sci., 62(7):1360-1374. doi:10.1016/j.icesjms.2005.05.007.

Saltzberg, R. (2019). Black sea bass gobbling up lobsters. MV Times. Retrieved from: https://www.mvtimes.com/2019/03/12/black-sea-bass-gobbling-lobsters/.

Schoener TW (1968) The Anolis lizards of Bimini: resource partitioning in a complex fauna. Ecology. 49:704-726.

Sedberry G. (1988). Food and feeding of black sea bass, Centropristis striata, in live bottom habitats in the south Atlantic Bight. J. Elisha. Mitch. Sci. Soc., 104(2), 3550 .

Shepherd, G. R. (1991). Meristic and morphometric variations in black sea bass north of Cape Hatteras, North Carolina. N. Am. J. Fish. Manage., 11:139-148.

Sherwood, O. A., Lehmann, M. F., Schubert, C. J., Scott, D. B., \& McCarthy, M. D. (2011). Nutrient regime shift in the western North Atlantic indicated by compound-specific $\delta 15 \mathrm{~N}$ of deep-sea gorgonian corals. P. Natl. Acad. Sci., (3), 1011. https://doi.org/10.1073/pnas. 1004904108

Sigman, D. M., Altabet, M. A., McCorkle, D.C., Francois, R., \& Fischer, G. (1999). The $\delta 15 \mathrm{~N}$ of nitrate in the Southern Ocean: Consumption of nitrate in surface waters. Global. Biogeochem. Cy., 13(4):1149-1166.

Sigman, D.M. Karsh, K.L., \& Casciotti, K.L. (2009). Nitrogen isotopes in the ocean. Ency. Ocean. Sci., 40-54. Doi: 10.1016/B978-012374473-9.00632-9.

Silfer, J. A., Engel, M. H., Macko, S. A., \& Jumeau, E. J. (1991). Stable carbon isotope analysis of amino acid enantiomers by conventional isotope ratio mass spectrometry and combined gas chromatography/isotope ratio mass spectrometry. Ana. Chem.., 63(4), 370-374. doi:10.1021/ac00004a014

Smith, E.P. \& Zaret, T.M. (1982). Bias in estimating niche overlap. Ecol. 63(5):12481253.

Steimle, F. W., \& Figley, W. (1996). The Importance of Artificial Reef Epifauna to Black Sea Bass Diets in the Middle Atlantic Bight. N. Am. J. Fish. Manage., 16(2), 433439. https://doi.org/10.1577/1548-8675(1996)016<0433:tioare>2.3.co;2

Steneck, R., Vavrinec, J. \& Leland, A. Accelerating Trophic-level Dysfunction in Kelp Forest Ecosystems of the Western North Atlantic. Ecosystems., 7, 323-332 (2004). https://doi.org/10.1007/s10021-004-0240-6.

Truesdale, C. L. (2018). "Fishery and Biological Characteristics of Jonah Crab (Cancer borealis) in Rhode Island Sound". Open Access Master's Theses. Paper 1206. https://digitalcommons.uri.edu/theses/1206.

Truesdale, C. L., Dalton, T. M., \& McManus, M. C. (2019). Fishers’ Knowledge and Perceptions of the Emerging Southern New England Jonah Crab Fishery. N. Am. J. Fish. Manage., 39: 951-963. doi:10.1002/nafm.10327

Vandermeer, J.H. (1972). Niche Theory. Ann. Rev. Ecol. Sys, 3:107-132. 
Vokhshoori, N. L., \& McCarthy, M. D. (2014). Compound- specific $\delta 15 \mathrm{~N}$ amino acid measurements in littoral mussels in the California upwelling ecosystem: A new approach to generating baseline $\delta 15 \mathrm{~N}$ isoscapes for coastal ecosystems. PLoS One, 9(6), e98087.

Wahle, R.A., Dellinger, L., Olszewski, S., \& Jekielek, P. (2015) American lobster nurseries of southern New England receding in the face of climate change. ICES. J. Mar. Sci.,72: i69-i78. Doi:10.1093/icesjms/fsv093.

Willis, T. V., Wilson, K. A., \& Johnson, B. J. (2017). Diets and Stable Isotope Derived Food Web Structure of Fishes from the Inshore Gulf of Maine. Estuar. Coast., 40(3), 889-904. https://doi.org/10.1007/s12237-016-0187-9

Woodward, G., Hildrew, A.G. (2002). Body size determinants of niche overlap and intraguild predation within a complex food web. J. Anim. Ecol., 71, 1063-1074.

Yarnes, C. T., \& Herszage, J. (2017). The relative influence of derivatization and normalization procedures on the compound-specific stable isotope analysis of nitrogen in amino acids. Rapid. Commun. Mass. Spe., 31(8), 693-704. doi: $10.1002 / \mathrm{rcm} .7832$

Zheng, J., Kruse, G.H. (2006). Recruitment variation of eastern Bering Sea crabs: climate forcing or top- down effects? Prog. Oceanogr., 68, 184-204. 


\section{TABLES}

\begin{tabular}{|l|lllllll|}
\hline Species & Cod & BSB & Cod & BSB & Cod & Cod & BSB \\
Location & BI & BI & NB & NB & BI & NB & NB \\
Season & Summer & Summer & Summer & Summer & Winter & Winter & Winter \\
\hline $\begin{array}{l}\text { Levins' } \\
\text { standardized } \\
\text { index }\end{array}$ & 0.01 & 0.04 & 0.33 & 0.43 & 0.11 & 0.21 & 0.04 \\
\hline
\end{tabular}

Table 1. Levin's standardized index based on diet of Atlantic cod and black sea bass in winter and summer in Narragansett Bay (NB) and Block Island (BI). 


\begin{tabular}{|c|c|c|c|c|c|}
\hline \multicolumn{6}{|c|}{ ANCOVA comparing TPCSIA and total length with season, species } \\
\hline & $\mathrm{DF}$ & Sum Sq & Mean Sq & $F$ value & $\operatorname{Pr}(>\mathrm{F})$ \\
\hline TL & 1 & 0.48 & 0.48 & 8.15 & 0.010 \\
\hline Season & 1 & 0.71 & 0.71 & 11.99 & 0.002 \\
\hline Species & 1 & 0.10 & 0.10 & 1.72 & 0.205 \\
\hline Residuals & 20 & 1.18 & 0.06 & & \\
\hline \multicolumn{6}{|l|}{ Tukey HSD } \\
\hline & diff & Iwr & upr & $\mathrm{p}$ adj & \\
\hline Winter-Summer & 0.3176405 & 0.1110302 & 0.52425 & 0.0044 & \\
\hline
\end{tabular}

\begin{tabular}{|c|c|c|c|c|c|c|}
\hline \multicolumn{7}{|c|}{ MANOVA comparing $\mathrm{C}$ and $\mathrm{N}$ isotope values with species and season } \\
\hline \multicolumn{7}{|l|}{ Response N: } \\
\hline & Df & & & Mean Sq & $\mathrm{F}$ value & $\operatorname{Pr}(>\mathrm{F})$ \\
\hline Species & & 1 & 0.064 & 0.064 & 0.086 & 0.77 \\
\hline Season & & 1 & 21.99 & 21.99 & 29.35 & 2.74E-07 \\
\hline Residuals & & 133 & 99.64 & 0.75 & & \\
\hline \multicolumn{7}{|l|}{ Response C: } \\
\hline & Df & & & Mean Sq & F value & $\operatorname{Pr}(>\mathrm{F})$ \\
\hline Species & & 1 & 0.82 & 0.81 & 3.44 & 0.066 \\
\hline Season & & 1 & 14.53 & 14.53 & 61.43 & $1.31 \mathrm{E}-12$ \\
\hline Residuals & & 133 & & & & \\
\hline
\end{tabular}

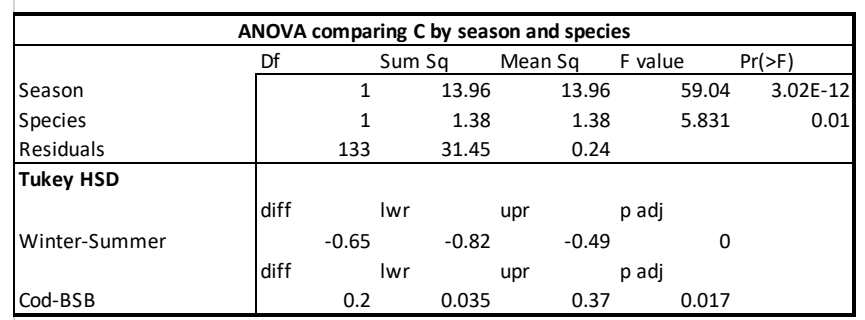

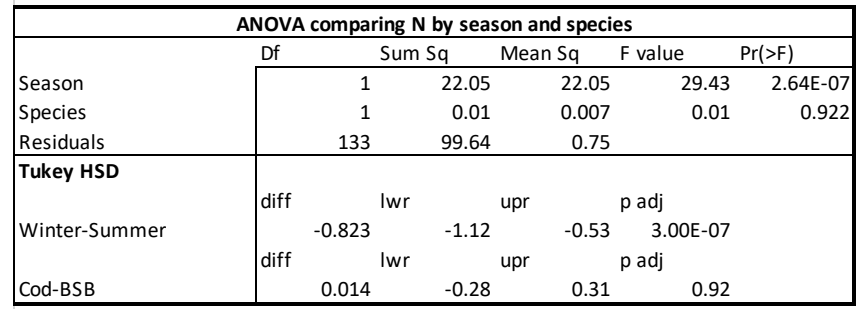

\begin{tabular}{|c|c|c|c|c|c|c|}
\hline \multicolumn{7}{|c|}{ ANOVA comparing Glu by season and species } \\
\hline \multirow[b]{2}{*}{ Species } & \multirow[t]{2}{*}{ Df } & \multicolumn{2}{|c|}{ Sum Sq } & Mean Sq & $F$ value & $\operatorname{Pr}(>F)$ \\
\hline & & L & 28.7 & 28.7 & 7.89 & 0.01 \\
\hline Season & & 1 & 0.43 & 0.43 & 0.12 & 0.73 \\
\hline Residuals & & & 76.43 & 3.6 & & \\
\hline \multirow[t]{2}{*}{ Tukey HSD } & & & & & & \\
\hline & diff & Iwr & & upr & $\mathrm{p}$ adj & \\
\hline \multirow[t]{2}{*}{ Winter-Summer } & & & -1.89 & 1.36 & 7.41E-01 & \\
\hline & diff & Iwr & & upr & padj & \\
\hline Cod-BSB & & & 0.58 & 3.86 & 0.01 & \\
\hline
\end{tabular}

\begin{tabular}{|c|c|c|c|c|c|c|}
\hline \multicolumn{7}{|c|}{ ANOVA comparing Phe by season and species } \\
\hline \multirow[b]{2}{*}{ Species } & \multirow[t]{2}{*}{$\mathrm{Df}$} & \multicolumn{2}{|c|}{ Sum Sq } & Mean Sq & $F$ value & $\operatorname{Pr}(>\mathrm{F})$ \\
\hline & & 1 & 27.62 & 27.62 & 23.14 & 0.00 \\
\hline Season & & 1 & 0.84 & 0.84 & 0.70 & 0.41 \\
\hline Residuals & & 21 & 25.07 & 1.19 & & \\
\hline \multirow[t]{2}{*}{ Tukey HSD } & & & & & & \\
\hline & diff & Iwr & & upr & $\mathrm{p}$ adj & \\
\hline \multirow[t]{2}{*}{ Winter-Summer } & & -2.15 & -3.07 & -1.22 & $9.40 \mathrm{E}-05$ & \\
\hline & diff & Iwr & & upr & $\mathrm{p}$ adj & \\
\hline Cod-BSB & & 0.36 & -0.58 & 1.3 & 0.44 & \\
\hline
\end{tabular}

Table 2. Linear regression model outputs and post-hoc test results for ANOVA, $M A N O V A$, and ANCOVA. 


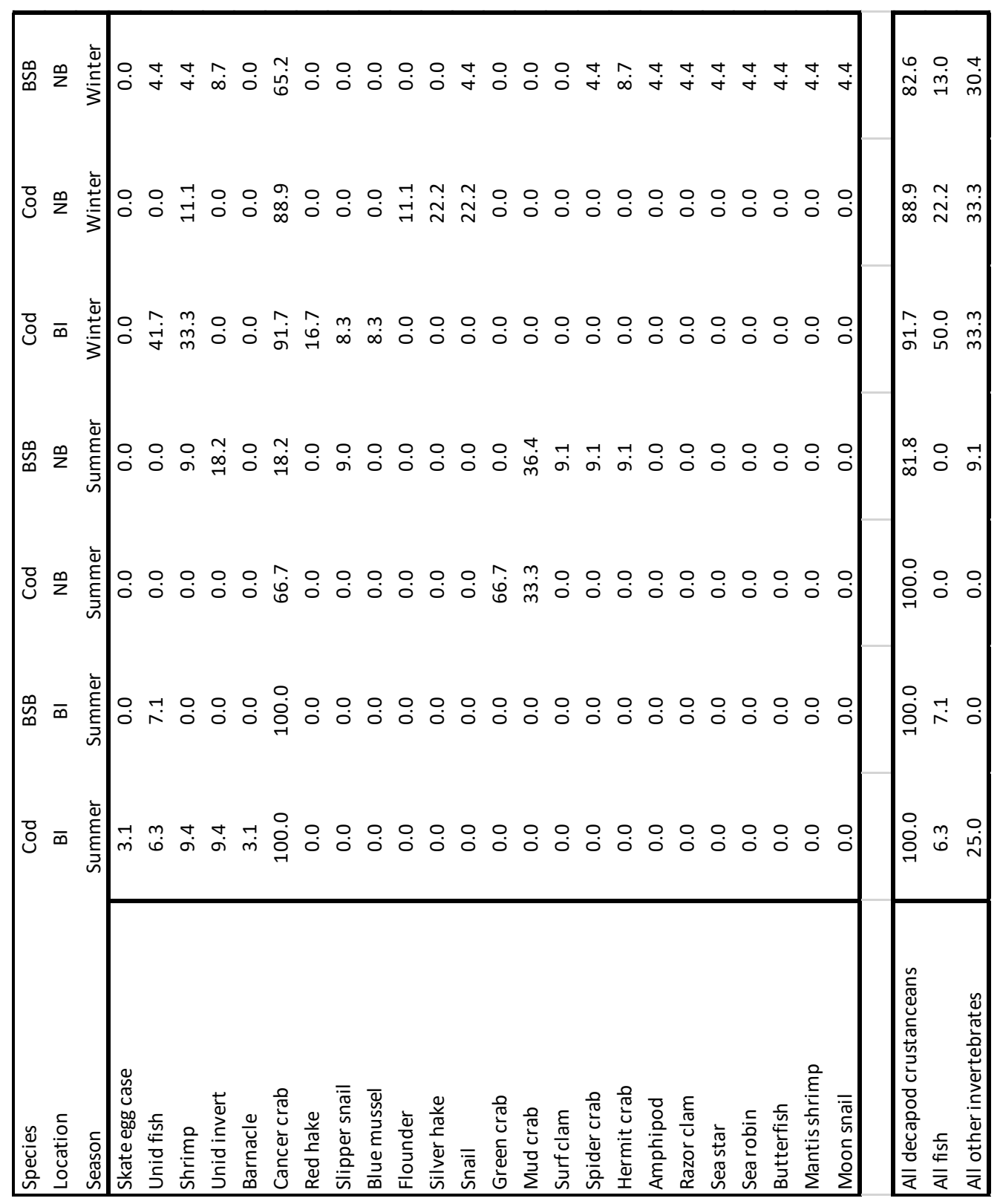

Table S1. Frequency of occurrence (\%) of prey items in diet of Atlantic cod and black sea bass in winter and summer in Narragansett Bay (NB) and Block Island (BI). 


\begin{tabular}{|l|ccccccc|}
\hline $\begin{array}{l}\text { Species } \\
\text { Location }\end{array}$ & $\begin{array}{c}\text { Cod } \\
\text { BI }\end{array}$ & $\begin{array}{c}\text { BSB } \\
\text { BI }\end{array}$ & $\begin{array}{c}\text { Cod } \\
\text { NB }\end{array}$ & $\begin{array}{c}\text { BSB } \\
\text { NB }\end{array}$ & $\begin{array}{c}\text { Cod } \\
\text { SI }\end{array}$ & $\begin{array}{c}\text { Cod } \\
\text { NB }\end{array}$ & $\begin{array}{c}\text { BSB } \\
\text { NB }\end{array}$ \\
\hline Cancer crab & 97.3 & 97.9 & 13.3 & 20.1 & 78.1 & 71.8 & 79.3 \\
Fish & 1.1 & 2.0 & 0.0 & 0.0 & 20.9 & 18.9 & 10.1 \\
Other & 1.6 & 0.1 & 0.0 & 49.9 & 1.0 & 9.3 & 10.6 \\
invertebrate & 0.0 & 0.0 & 75.8 & 0.0 & 0.0 & 0.0 & 0.0 \\
Green crab & 0.0 & 10.8 & 30.0 & 0.0 & 0.0 & 0.0 \\
Mud crab & 0.0 & 0.0 & Summer & Summer & Winter & Winter & Winter \\
\hline
\end{tabular}

Table S2. Proportion of total wet weight (\%) of prey items in diet of Atlantic cod and

black sea bass in winter and summer in Narragansett Bay (NB) and Block Island (BI). 


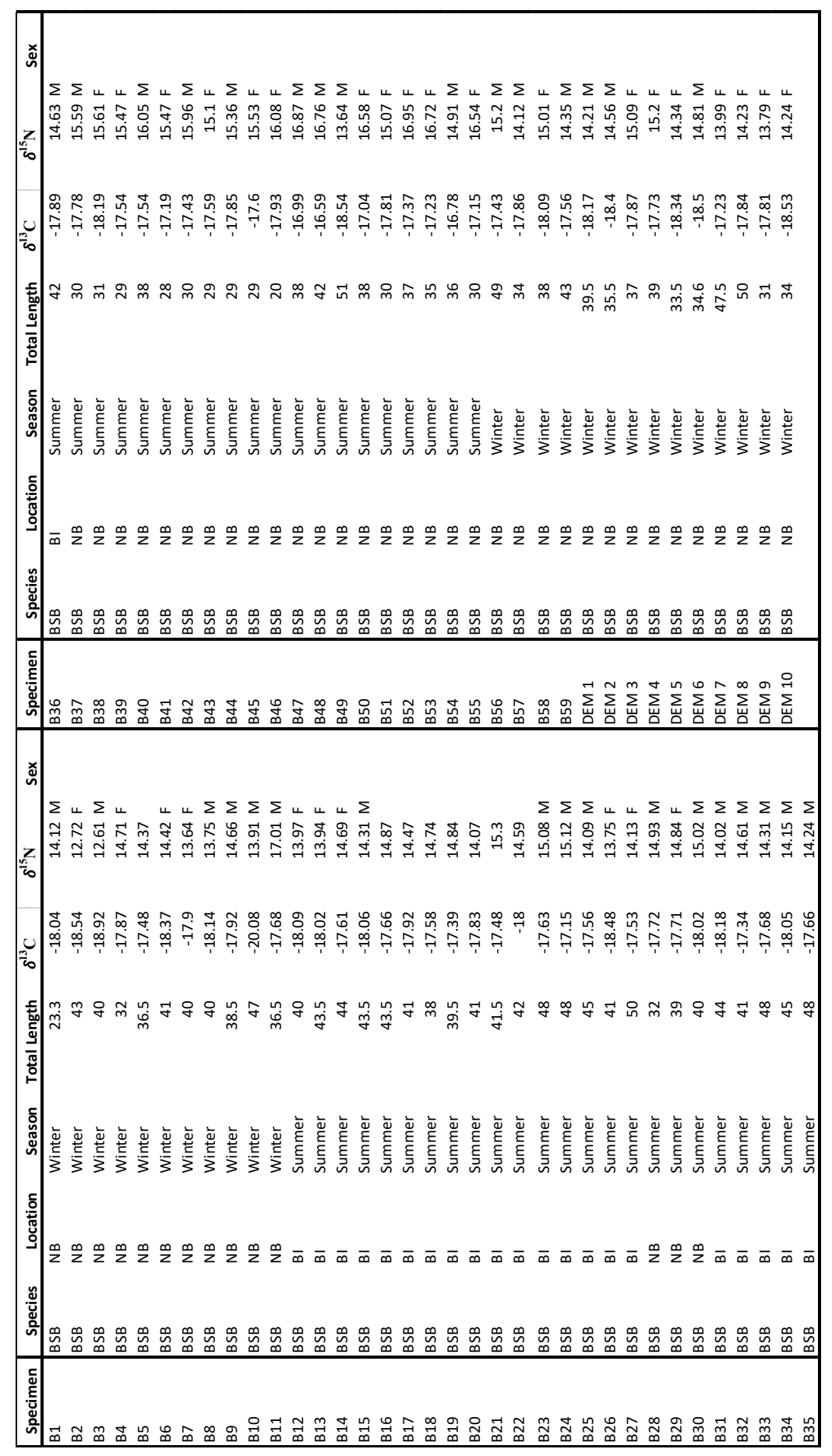

Table S3. Individual black sea bass specimen data including location and season of capture, total length, sex, bulk $\delta^{15} \mathrm{~N}$ and bulk $\delta^{13} \mathrm{C}$. 


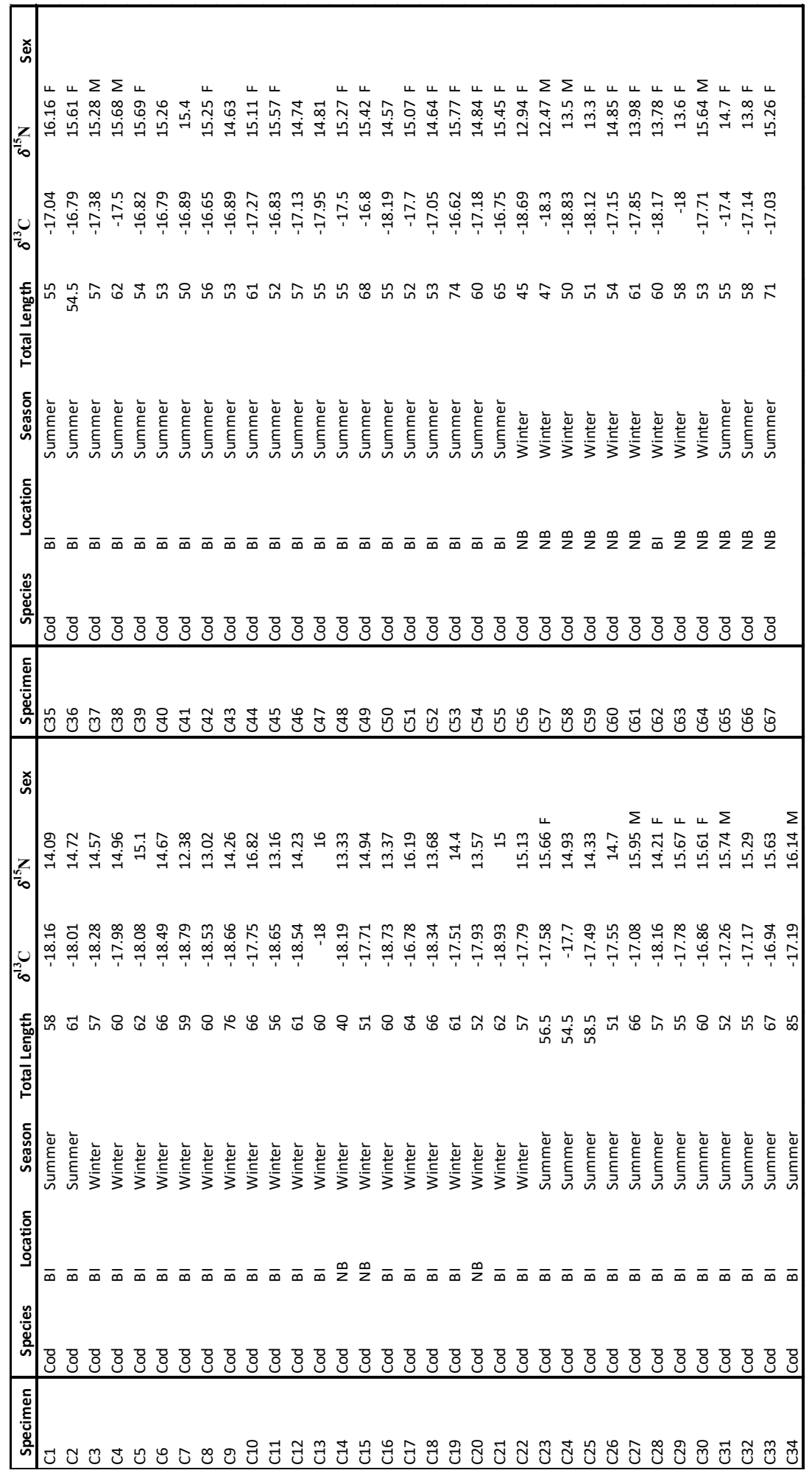

Table S4. Individual Atlantic cod specimen data including location and season of capture, total length, sex, bulk $\delta^{15} \mathrm{~N}$ and bulk $\delta^{13} \mathrm{C}$. 


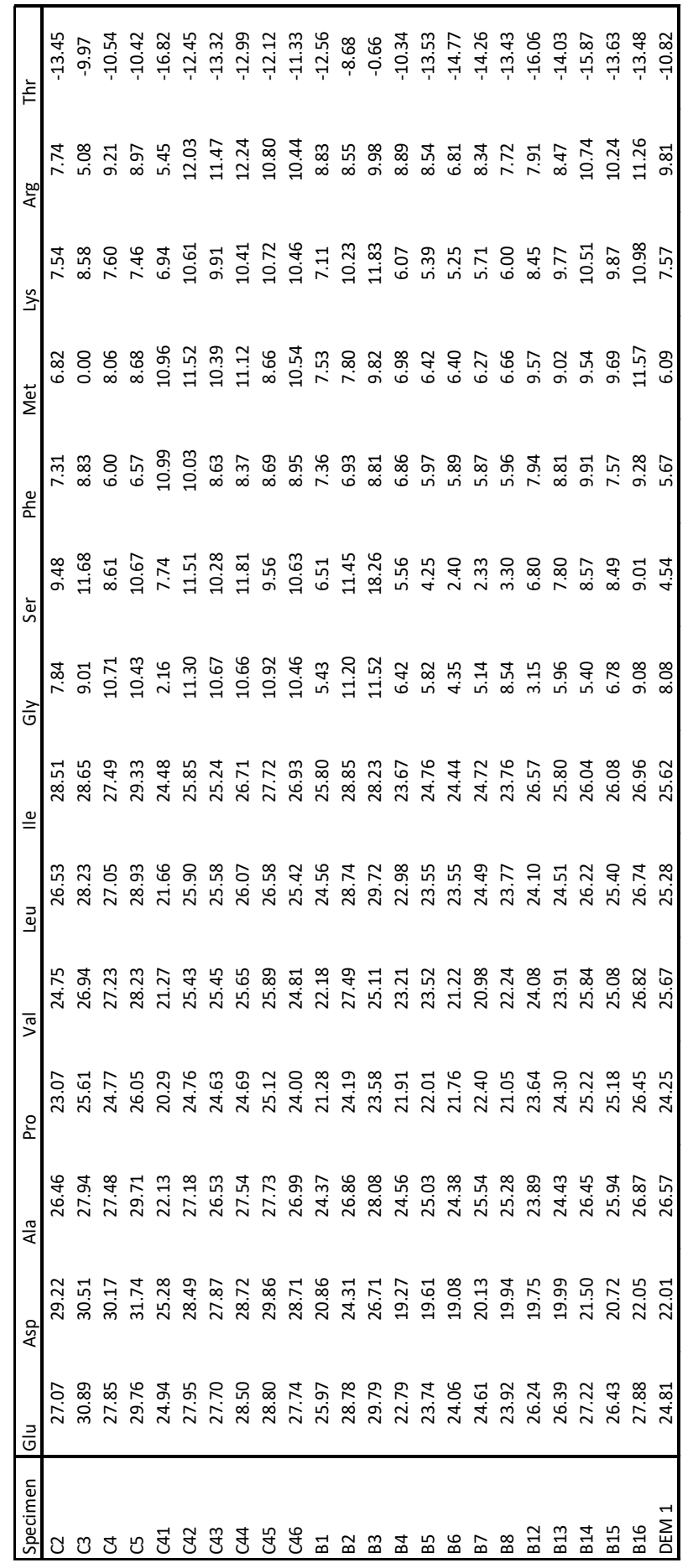

Table S5. Individual Atlantic cod and black sea bass data for each of the 14 amino acids sampled for $\delta^{15} \mathrm{~N}$ CSIA-AA. 


\section{FIGURES}

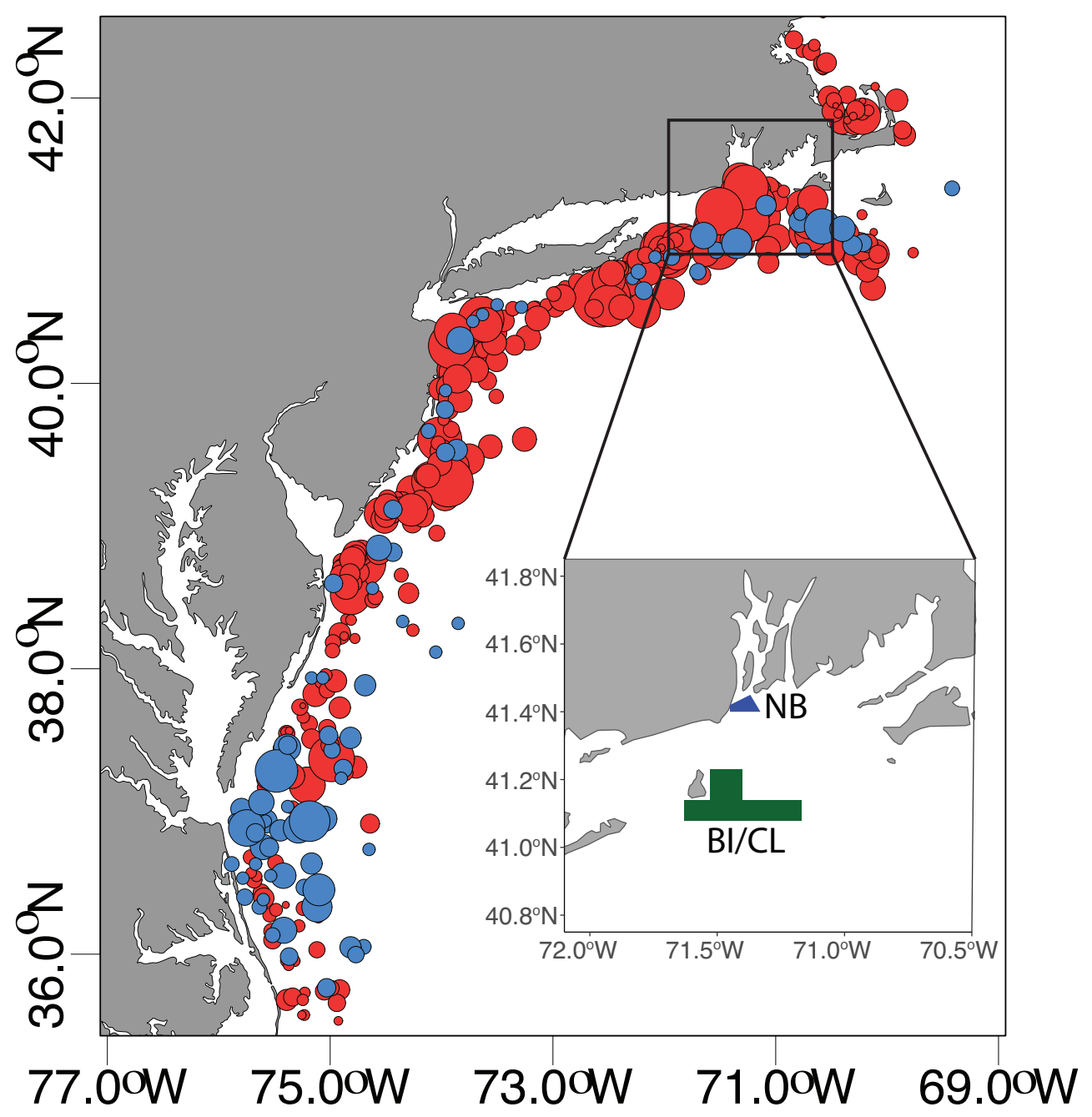

Figure 1. Map of the Northeast US Shelf showing catch of black sea bass in the NEFSC fall trawl survey between 1970-1974 in blue and 2015-2019 in red. Inset of sampling locations at NB (Narragansett Bay) and BI/CL (Block Island and Cox Ledge) (Northeast Fisheries Science Center, 2020: Fall Bottom Trawl Survey). 


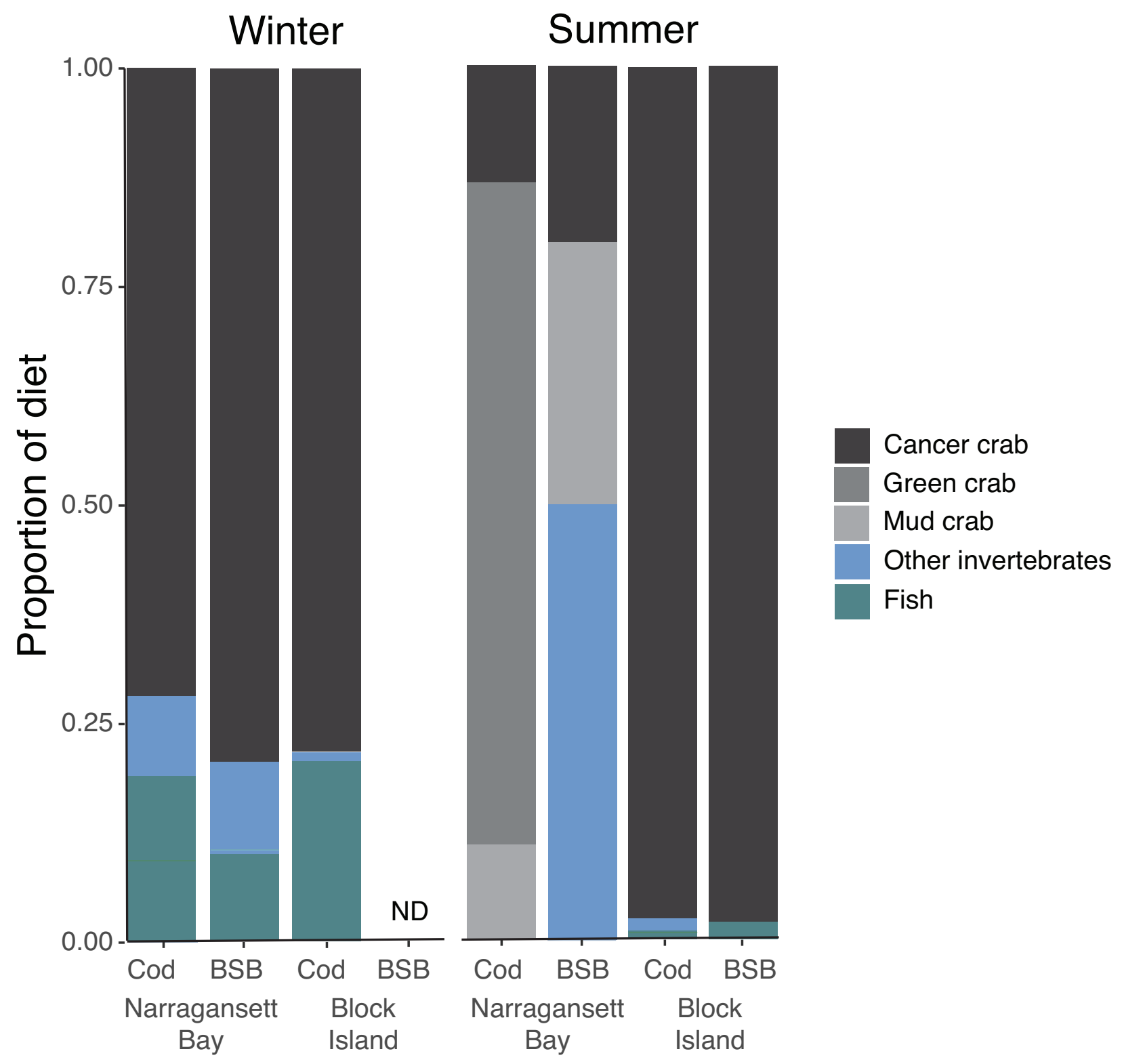

Figure 2. Stomach content analysis for Atlantic cod and black sea bass in winter and summer at Block Island and Narragansett Bay presented as proportion of total wet weight. 

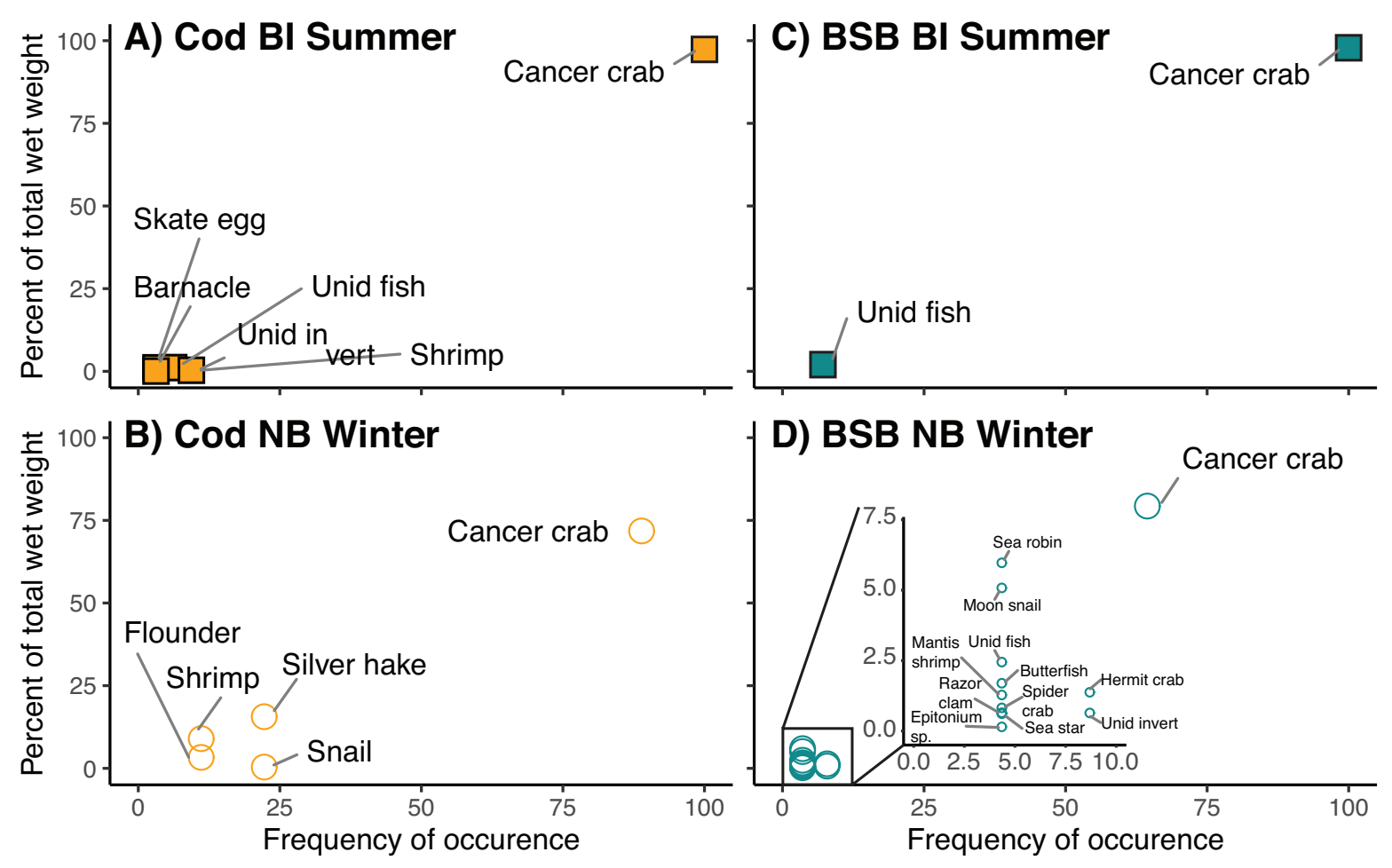

Figure 3. Predator feeding strategy and prey importance for Atlantic cod and black sea bass (BSB) at Block Island (BI) and Narragansett Bay (NB) represented as the frequency of prey occurrence and the proportion of the total wet weight made of up that prey item. 

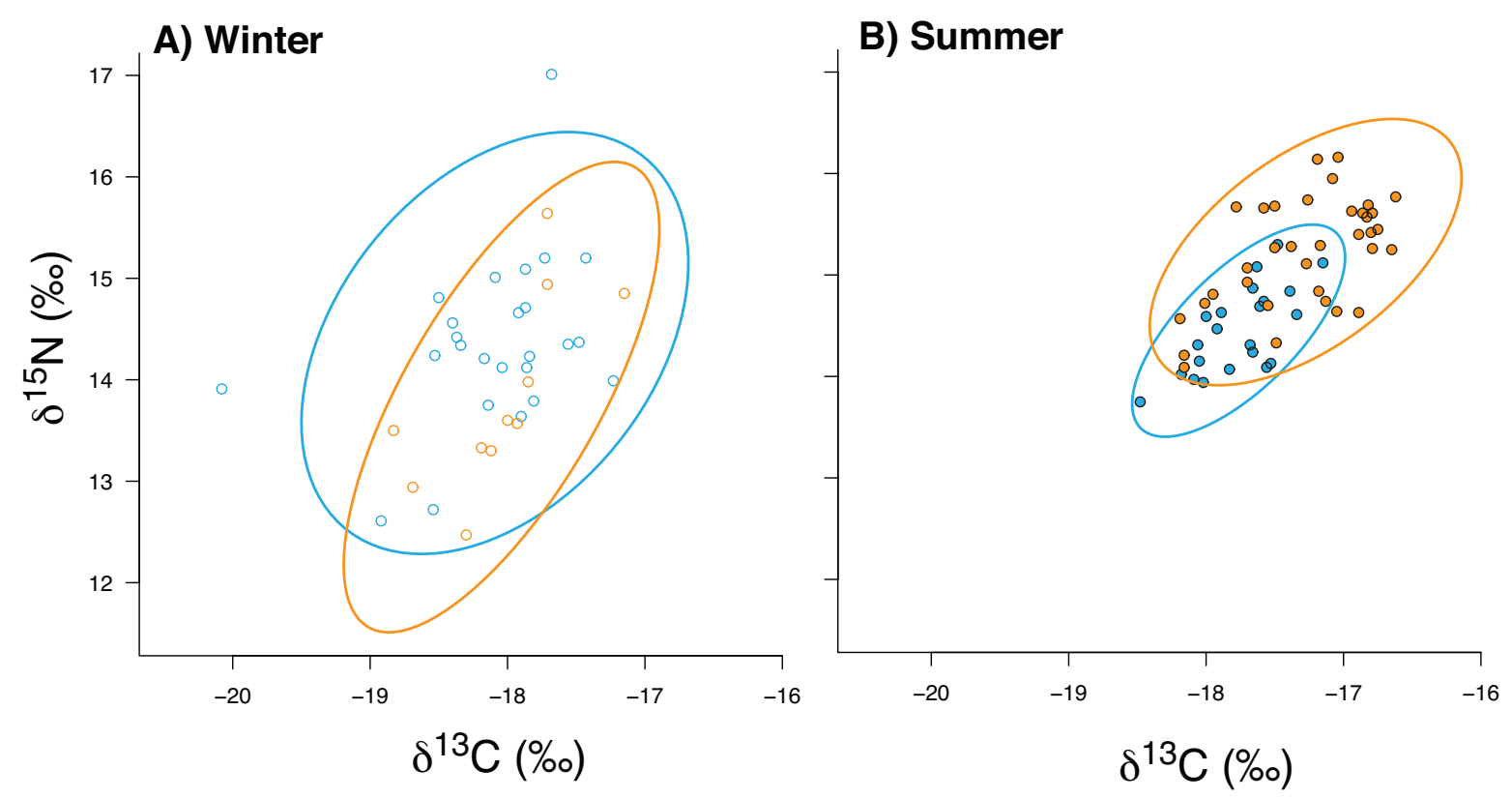

Figure 4. Standard ellipse area (SEA) analysis of overlap between bulk $\delta^{15} \mathrm{~N}$ and $\delta^{13} \mathrm{C}$ isotope data for Atlantic cod (orange) and black sea bass (cyan) containing $95 \%$ of the data in Winter (A, open circles) and Summer (B, closed circles). 


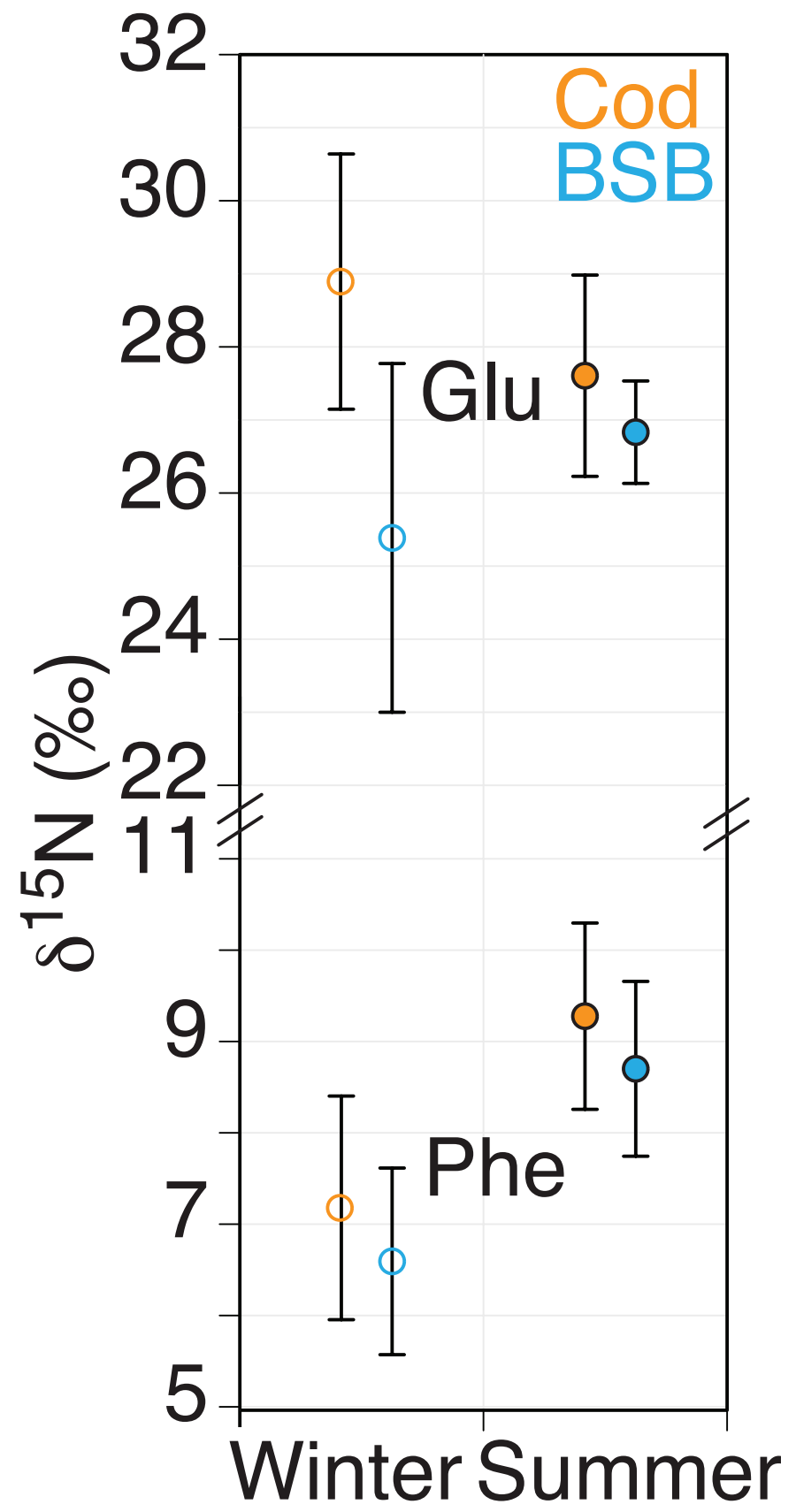

Figure $5 . \delta^{15} \mathrm{~N}$ values for glutamic acid (Glu) and phenylalanine (Phe) analyzed with CSIA-AA for Atlantic cod and black sea bass muscle in winter and summer. All Atlantic cod samples are from BI while summer black sea bass samples are from BI and winter samples are from NB. 


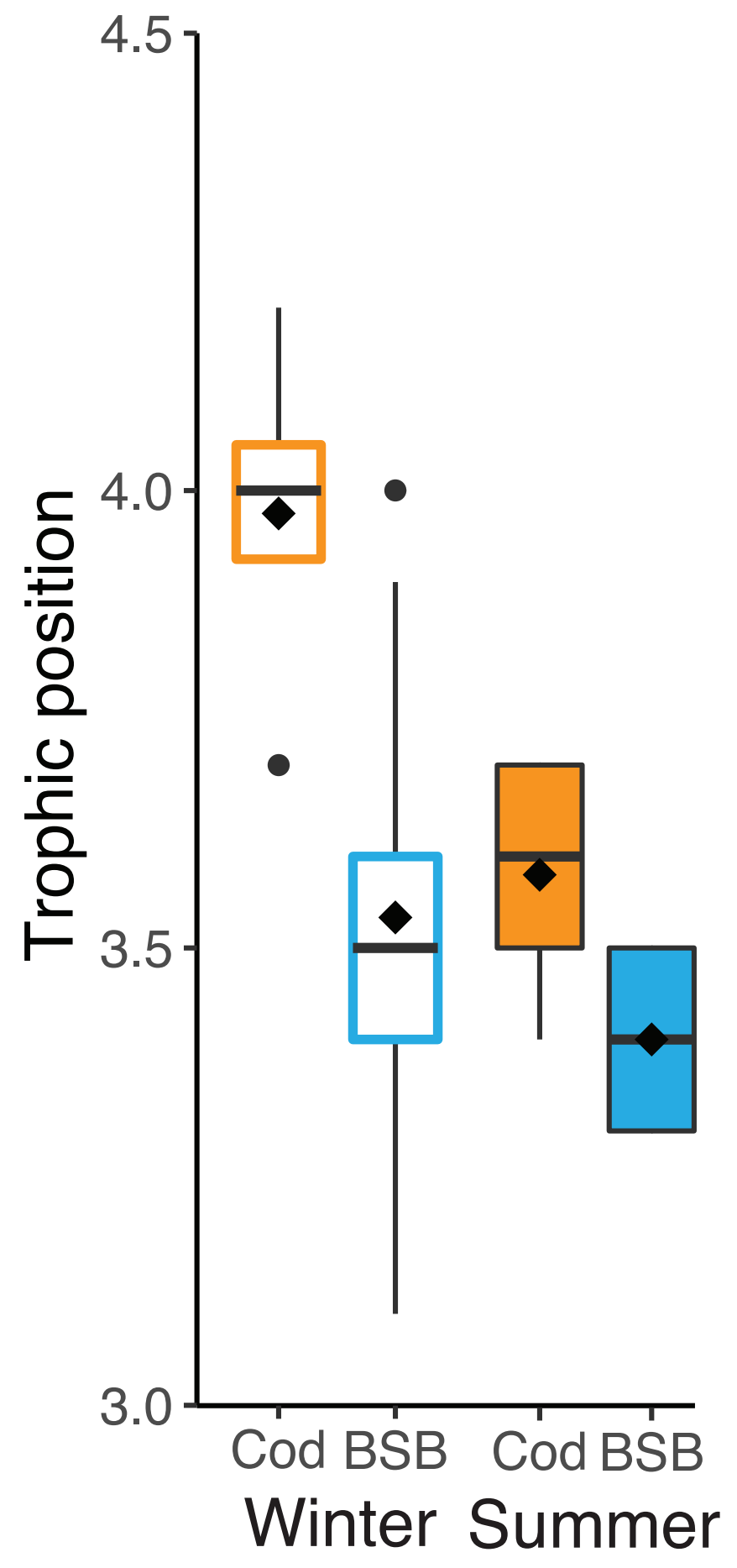

Figure 6. Trophic position as calculated by CSIA-AA of Atlantic cod (blue) and black sea bass (orange) in summer (filled bars) and winter (unfilled bars). All Atlantic cod samples are from BI while summer black sea bass samples are from BI and winter samples are from NB. 


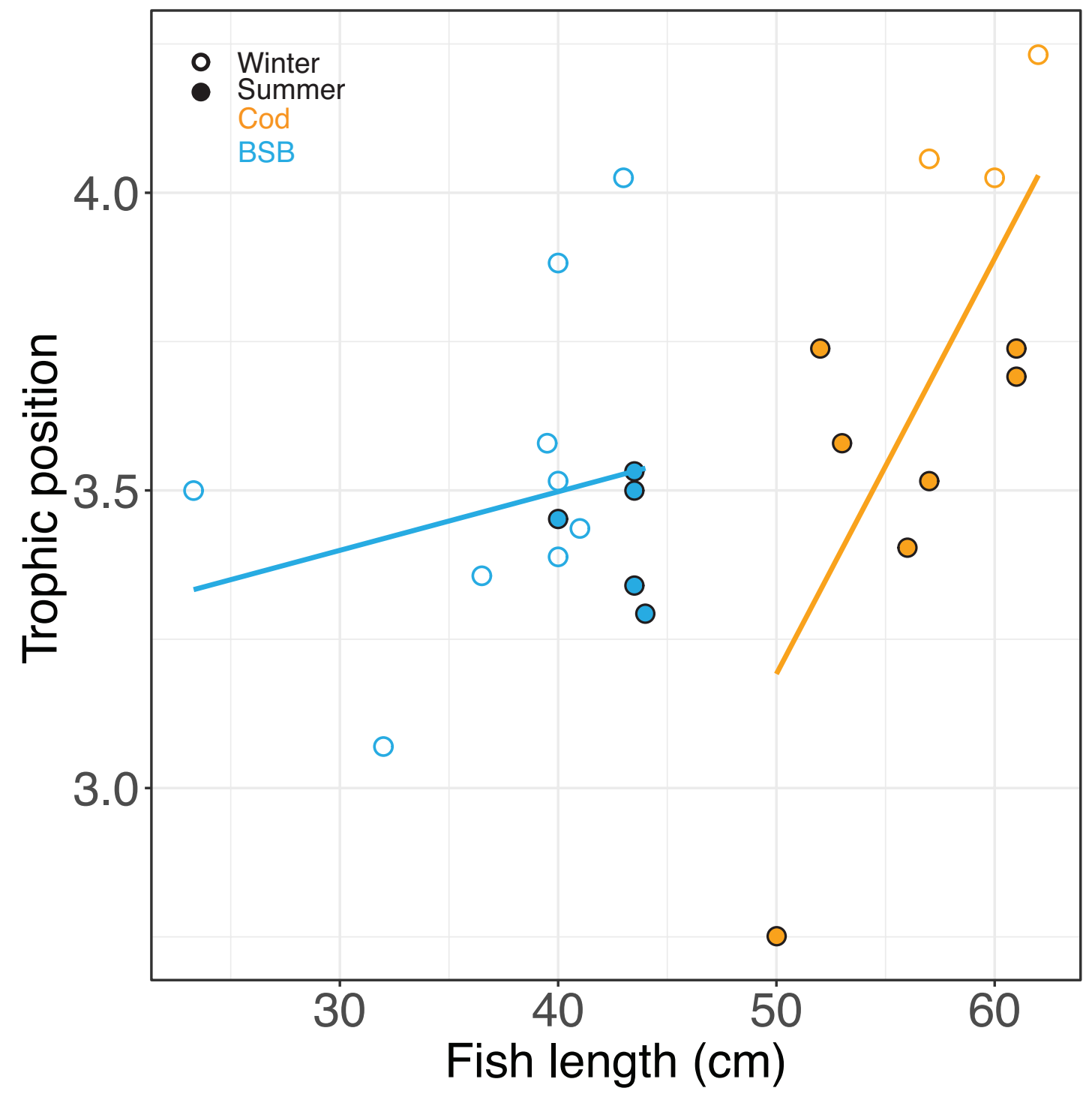

Figure 7. Trophic position compared with fish total length for Atlantic cod (orange) and black sea bass (cyan) in summer (closed circles) and winter (open circles). All Atlantic cod samples are from BI while summer black sea bass samples are from BI and winter samples are from NB. 


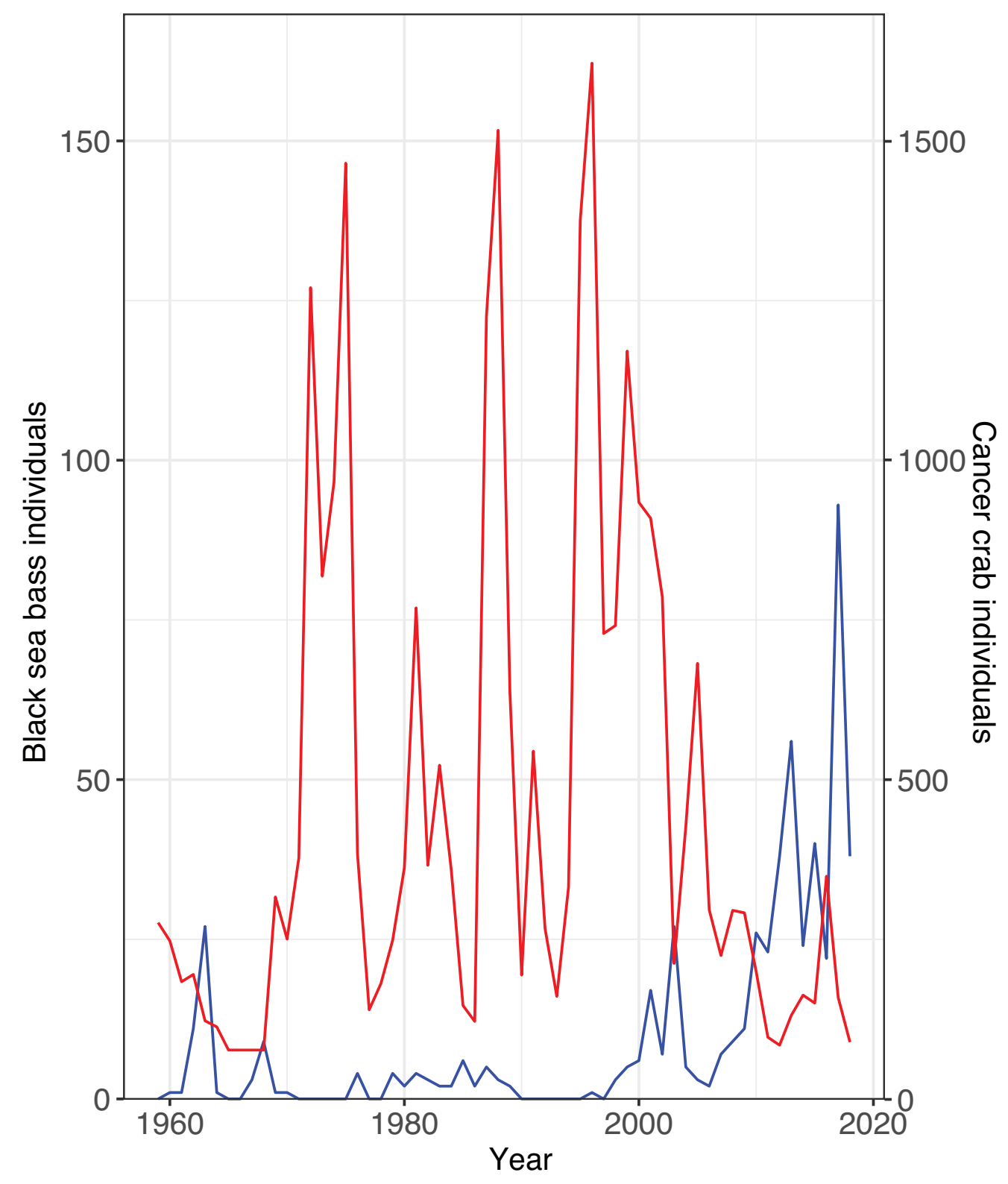

Figure 8. Count of cancer crabs (red) and black sea bass (blue) caught in the URI-GSO fish trawl survey 1959-2019. 

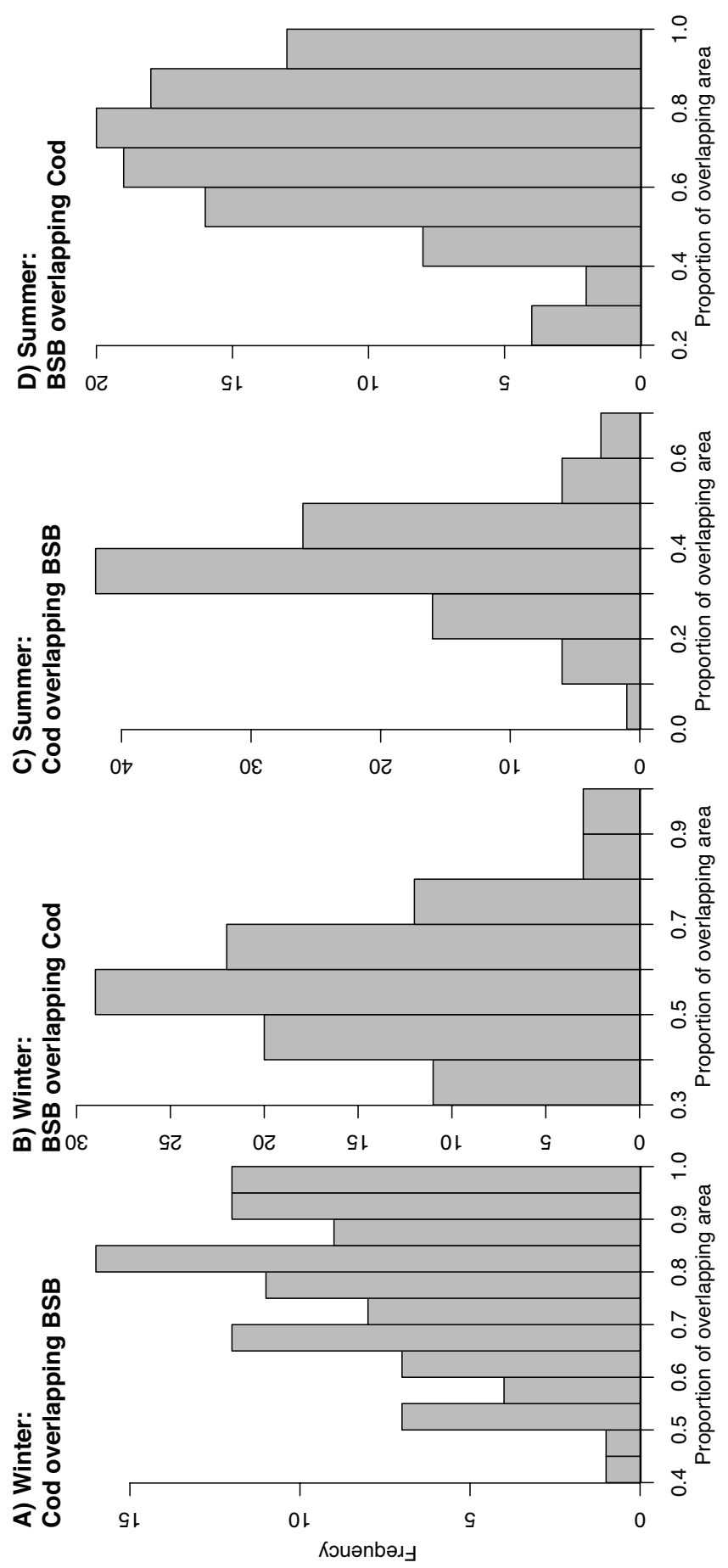

Figure S1. Result of the Bayesian standard ellipse area estimate of overlap of bulk isotope data for Atlantic cod and black sea bass (BSB). (A) The proportion of the Cod ellipse overlapping the BSB ellipse in winter, (B) The proportion of the BSB ellipse overlapping the Cod ellipse in winter, $(C)$ The proportion of the Cod ellipse overlapping the BSB ellipse in summer, (D) The proportion of the BSB ellipse overlapping the Cod ellipse in summer. 


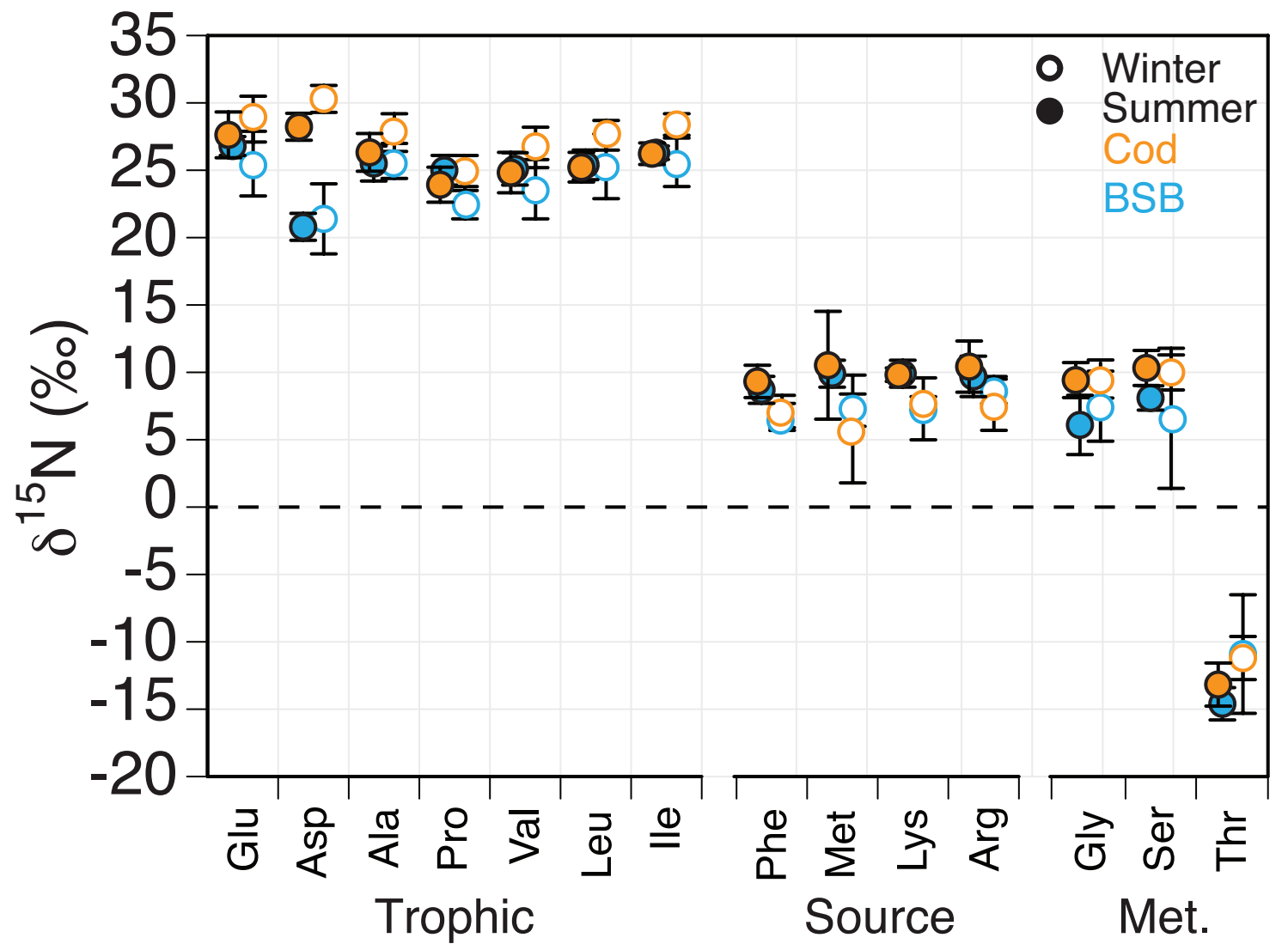

Figure S2. $\delta^{15} \mathrm{~N}$ values for all 14 amino acids analyzed with CSIA-AA for Atlantic cod (orange) and black sea bass (cyan) muscle in winter (open circles) and summer (closed circles). All Atlantic cod samples are from BI while summer black sea bass samples are from $\mathrm{BI}$ and winter samples are from NB. 